\title{
Development of an Integrated Structure for the Tri-Generation of Power, Liquid Carbon Dioxide, and Medium Pressure Steam Using a Molten Carbonate Fuel Cell, a Dual Pressure Linde-Hampson Liquefaction Plant, and a Heat Recovery Steam Generator
}

\author{
Bahram Ghorbani (D)
}

check for updates

Citation: Ghorbani, B. Development of an Integrated Structure for the Tri-Generation of Power, Liquid Carbon Dioxide, and Medium Pressure Steam Using a Molten Carbonate Fuel Cell, a Dual Pressure Linde-Hampson Liquefaction Plant, and a Heat Recovery Steam Generator. Sustainability 2021, 13, 8347. https:// doi.org/10.3390/su13158347

Academic Editors:

Amir Ebrahimi-Moghadam and Mohammad Hossein Ahmadi

Received: 15 June 2021

Accepted: 16 July 2021

Published: 27 July 2021

Publisher's Note: MDPI stays neutral with regard to jurisdictional claims in published maps and institutional affiliations.

Copyright: (C) 2021 by the author. Licensee MDPI, Basel, Switzerland. This article is an open access article distributed under the terms and conditions of the Creative Commons Attribution (CC BY) license (https:/ / creativecommons.org/licenses/by/ $4.0 /)$.
Faculty of Engineering Modern Technologies, Amol University of Special Modern Technologies, Amol 46156-64616, Iran; b.ghorbani@ausmt.ac.ir

\begin{abstract}
Due to the increase in energy consumption and energy prices, the reduction in fossil fuel resources, and increasing concerns about global warming and environmental issues, it is necessary to develop more efficient energy conversion systems with low environmental impacts. Utilizing fuel cells in the combined process is a method of refrigeration and electricity simultaneous production with a high efficiency and low pollution. In this study, a combined process for the tri-generation of electricity, medium pressure steam, and liquid carbon dioxide by utilizing a molten carbonate fuel cell, a dual pressure Linde-Hampson liquefaction plant and a heat recovery steam generator is developed. This combined process produces $65.53 \mathrm{MW}$ of electricity, $27.8 \mathrm{~kg} / \mathrm{s}$ of medium pressure steam, and $142.9 \mathrm{~kg} / \mathrm{s}$ of liquid carbon dioxide. One of the methods of long-term energy storage involves the use of a carbon dioxide liquefaction system. Some of the generated electricity is used in industrial and residential areas and the rest is used for storage as liquid carbon dioxide. Liquid carbon dioxide can be used for peak shavings in buildings. The waste heat from the Linde-Hampson liquefaction plant is used to produce the fuel cell inlet steam. Moreover, the exhaust heat of the fuel cell and gas turbine would be used to produce the medium pressure steam. The total efficiency of this combined process and the coefficient of performance of the refrigeration plant are $82.21 \%$ and 1.866 , respectively. The exergy analysis of this combined process reveals that the exergy efficiency and the total exergy destruction are $73.18 \%$ and $102.7 \mathrm{MW}$, respectively. The highest rate of exergy destruction in the hybrid process equipment belongs to the fuel cell (37.72\%), the HX6 heat exchanger $(8.036 \%)$, and the HX7 heat exchanger $(6.578 \%)$. The results of the sensitivity analysis show that an increase in the exit pressure of the V1 valve by $13.33 \%$ would result in an increase in the refrigeration energy by $2.151 \%$ and a reduction in the refrigeration cycle performance by $9.654 \%$. Moreover, by increasing the inlet fuel to the fuel cell, the thermal efficiency of the whole combined process rises by $18.09 \%$, and the whole exergy efficiency declines by $12.95 \%$.
\end{abstract}

Keywords: integrated structure; CCHP system; fuel cell; Linde-Hampson liquefaction plant; heat recovery steam generator; exergy analysis

\section{Introduction}

Fuel cells are one of the suitable alternatives to conventional power generation technologies from fossil fuels. They have been of interest to many researchers in recent years due to their low pollution and high performance [1]. Molten carbonate fuel cells (MCFC), as well as solid oxide fuel cells, are high-temperature fuel cells. The exhaust gases from them can be used in devices such as gas turbines and heat recovery steam generators (HRSG) [2] Various studies on the modeling of MCFCs have been performed. The complexity of the studied models ranges from simple and brief models to more complex 3-dimensional models of fuel cells [3]. Haghighat et al. [4] analyzed a hybrid MCFC and a gas turbine 
unit by an external reforming reaction from an economical, technical, environmental, and optimization point of view. The output of the exergy assessment in the optimal state showed that the exergy efficiency increased by up to 51.7\%. Mamaghani et al. [5] evaluated the technical, economical, and environmental aspects of an integrated plant with an MCFC, a gas turbine, and an organic Rankine power generation unit by the internal reforming reaction. Inlet fuel to the fuel cell was considered to be pure methane with a heating value of $50 \mathrm{MJ} / \mathrm{kg}$. The results of the optimization showed that the exergy efficiency increased by up to $54.9 \%$. Marefati et al. [6] performed an exergy analysis of a hybrid structure for the cogeneration of heat and power which consisted of an MCFC, a thermoelectric generator, a gas turbine, and solar collectors. The results of the energy analysis by the HYSYS package and the MATLAB programming showed an increase of $64.93 \%$ and $31.57 \%$ in the total performance and the electrical performance of the developed hybrid unit, respectively. Furthermore, the exergy efficiency and exergy destruction of the hybrid plant were found to be $41.2 \%$ and $59.12 \%$, respectively.

Ahmadi et al. [7] conducted a multi-objective optimization of a hybrid electricity generation unit employing a MCFC and a Braysson cycle. To do so, they investigated several parameters of the integrated structure such as the flow density of the fuel cell, the gas turbine inlet temperature, and the effect of the heating part which transfers heat to the electricity generation cycle. Ahmadi et al. [8] optimized a freshwater production hybrid structure by combining the MCFC, a Stirling engine, and reverse osmosis water desalination. They implemented two methods of optimization for analyzing and improving the performance of the developed system. The selection of the final results from the obtained Pareto fronts was completed using the genetic algorithm and three well-known methods, namely, the fuzzy, LINMAP, and TOPSIS methods. Jokar et al. [9] investigated a multi-objective optimization of the hybrid structure for the generation of electricity and heat combining the MCFC and carbon dioxide $\left(\mathrm{CO}_{2}\right)$ power generation unit (Brayton supercritical $\mathrm{CO}_{2}$ unit). The final results were selected by three well-known methods, namely, the fuzzy, LINMAP, and TOPSIS methods, from the Pareto fronts obtained by the genetic algorithm. Ryu et al. [10] developed three hybrid electricity generation structures using the outlet gases from the MCFCs at different positions of the supercritical $\mathrm{CO}_{2}$ power generation cycle. The output of the economic assessment revealed that the use of the supercritical carbon dioxide cycle in the MCFC ventilation unit is more affordable when the heating costs less than USD 28 per kilocalorie and the heat exchanger cost is less than USD 100 per kW. Haghighat et al. [11] carried out a thermodynamic, economic, and environmental assessment of an integrated plant of the MCFC, power generation cycle, refrigeration cycle, and the desalination unit. The developed hybrid structure produced $1439 \mathrm{~kW}$ of electricity, $132.8 \mathrm{~kW}$ of refrigeration, $550.9 \mathrm{~kW}$ of heat, and $356.7 \mathrm{~kg} / \mathrm{h}$ of freshwater. The output of the optimization assessment showed that energy and exergy efficiencies increased from $47 \%$ to $51.9 \%$ and $48.7 \%$ to $79.9 \%$, respectively. The simplified models estimate the performance of the fuel cell with moderate accuracy while the complex models require lots of iterative loops that extend the computation time. Therefore, developing an accurate model with a reasonable response speed and reliable results is one of the goals of many researchers [12]. Carrette et al. [13] studied the principles and applications of fuel cells by emphasizing the benefits of fuel cells compared to conventional techniques. Then, different types of fuel cells and a comparison between the theoretical efficiency and the actual efficiency of fuel cells with combustion engines was discussed. Rashidi et al. [14] reviewed the performance of a hybrid system including the turboexpander and the MCFC installed in Toronto, Canada. The thermodynamic analysis of the system revealed that the energy efficiency of the whole system was $60 \%$. Kang et al. [15] simulated an integrated system including the molten carbonate fuel cell and investigated the influence of key parameters on plant efficiency. The results showed that to increase the efficiency of the MCFC's system, its heat waste should be utilized in other energy systems. Moreover, the influence of the size and the operating conditions of the systems had little effect on their efficiency. 
Carbon dioxide has better physical properties than air for storage since it has a critical temperature and pressure of $31^{\circ} \mathrm{C}$ and $37.37 \mathrm{MPa}$, respectively. Therefore, liquid $\mathrm{CO}_{2}$ can be used as a working fluid in energy storage structures [16,17]. Aliyon et al. [18] investigated $\mathrm{CO}_{2}$ liquefaction units by several methods, such as the utilization of the vapor compression refrigeration cycle, the water-ammonia absorption refrigeration unit, and the Linde-Hampson refrigeration cycles. The simulation results revealed that the performance coefficient was the lowest (0.537) for the water-ammonia absorption refrigeration unit and was the highest (2.617) for the compression refrigeration cycle. Xu et al. [16] developed two combined power generation systems for peak hours by liquefying carbon dioxide and air. Solar collectors were used to heat the $\mathrm{CO}_{2}$ liquefaction unit. The round trip and exergy efficiencies of the $\mathrm{CO}_{2}$ liquefaction unit were $45.35 \%$ and $67.2 \%$, respectively. Shakib et al. [19] utilized the waste heat from a gas turbine to produce steam in the HRSG system. This steam was implemented in the multi-stage flash distillation. Then they optimized the main parameters of the developed hybrid system by the genetic algorithm and particle swarm optimization. With these optimization algorithms, the exergy efficiency of the developed integrated structure increased from 3.5\% to $4 \%$. Moreover, Hosseini et al. [20] performed exergy, economic, and risk analyses on a freshwater production integrated structure using a gas turbine to produce steam in the HRSG system and the multistage flash distillation. Akrami et al. [21] performed exergy and exergoeconomic analyses of three power and $\mathrm{CO}_{2}$ generation integrated structures using a new hybrid cycle of biomass gasification, a gas turbine, a MCFC, an organic Rankine unit, and a $\mathrm{CO}_{2}$ separation and liquefaction unit. The results of the exergy assessment of the three hybrid structures revealed that the maximum value of exergy efficiency of the entire integrated unit and its specific power consumption parameters were $43.95 \%$ and $854.9 \mathrm{kgCO}_{2} / \mathrm{MWh}$, respectively. Ebrahimi-Moghadam et al. [22] investigated a combined structure for the cogeneration of power and heat in a residential complex using the Kalina power cycle and a gas turbine. The simulation results showed that the thermal efficiency, exergy efficiency, and period of return were $69.43 \%, 37.90 \%$, and 3.34 years, respectively. Shokouhi Tabrizi et al. [23] applied a $\mathrm{CO}_{2}$ recompression Brayton unit and solar collectors in a city gas station to preheat the natural gas and generate power. The results showed that the exergy efficiency and period of return were $41 \%$ and 4 years, respectively. Ebrahimi-Moghadam et al. [24] investigated a hybrid configuration for the tri-generation of power, cooling, and heat by the Kalina unit and the ejector refrigeration plant and a regenerative turbine system. The simulation results revealed that the thermal, electrical, and exergy efficiencies were $36.55 \%, 37.87 \%$, and $38.85 \%$, respectively. Ghorbani et al. [25] investigated a new liquid $\mathrm{CO}_{2}$ cryogenic energy storage system for peak shaving by a post-combustion structure, a Linde-Hampson liquefaction unit, an organic Rankine, and gas turbine plants. Pinch, exergy, and sensitivity analyses were used to evaluate the developed integrated structure. Ebrahimi-Moghadam et al. [26] proposed a novel integrated structure for the cogeneration of the power and heat required by the gas pressure drop station. The simulation results revealed that the thermal and exergy efficiencies were $42.51 \%$, and $38.17 \%$, respectively. Ebrahimi-Moghadam et al. [27] evaluated a novel hybrid system for the trigeneration of power, cold, and heat using a gas turbine, a Kalina power production unit, and ejector systems. The combined process produced $1025.9 \mathrm{~kW}$ of power, $1642.3 \mathrm{~kW}$ of heat, and $304.9 \mathrm{~kW}$ of cooling.

There are some studies in the literature that suggest useful guidelines to enhance the efficiency of cogeneration systems. In fact, the principal purpose of the reported investigations is to optimize the necessary thermal energy, generated electricity, and economic prices of the process and finally to decrease the negative environmental impacts. To the best of our knowledge, no systematic investigation has been conducted in relation to the use of the waste heat and electricity generated in fuel cell systems in the $\mathrm{CO}_{2}$ liquefaction industry. In this study, an integrated structure for the tri-generation of electricity, steam, and liquid carbon dioxide is developed using a molten carbonate fuel cell, a dual pressure Linde-Hampson liquefaction plant, and a heat recovery steam generator. Energy, exergy, 
and sensitivity assessments are employed to investigate the thermodynamic laws and the main parameters of the combined system. After compression and preheating, the liquid $\mathrm{CO}_{2}$ can be used for peak shaving in industrial and residential areas.

\section{Process Description}

Fuel cells are a competitive alternative to conventional power generation technologies from fossil fuels due to their low pollution and high efficiency, especially in small-scale and scattered power generation [28]. The MCFCs are kind of high-temperature fuel cell which have many advantages but have received less attention. The high operating temperature of this type of fuel cell makes it compatible with different fuels. On the other hand, the high heat generated by the fuel cell can be recovered for heating applications [29]. In MCFCs, hydrogen is delivered to the anode and the cathode receives carbon dioxide and air to produce heat and electricity due to chemical reactions within the fuel cell. Since the MCFC operates at high temperatures, different hydrocarbon fuels can be used. Before the injection of hydrocarbon fuels, a reformer can be used to convert hydrocarbons to hydrogen using water vapor. Due to the endothermic reaction of the reformer, the heat required for this reaction is provided by electrochemical reactions inside the fuel cell. In the developed MCFC unit, the chemical energy of the natural gas is converted to power. The block diagram for the production of liquid $\mathrm{CO}_{2}$, electricity, and medium pressure steam using a molten carbonate fuel cell, a Linde-Hampson liquefaction plant, and a HSRG is illustrated in Figure 1. This combined configuration produces $65.53 \mathrm{MW}$ of electricity, $27.80 \mathrm{~kg} / \mathrm{s}$ of medium pressure steam, and $142.9 \mathrm{~kg} / \mathrm{s}$ of liquid carbon dioxide.

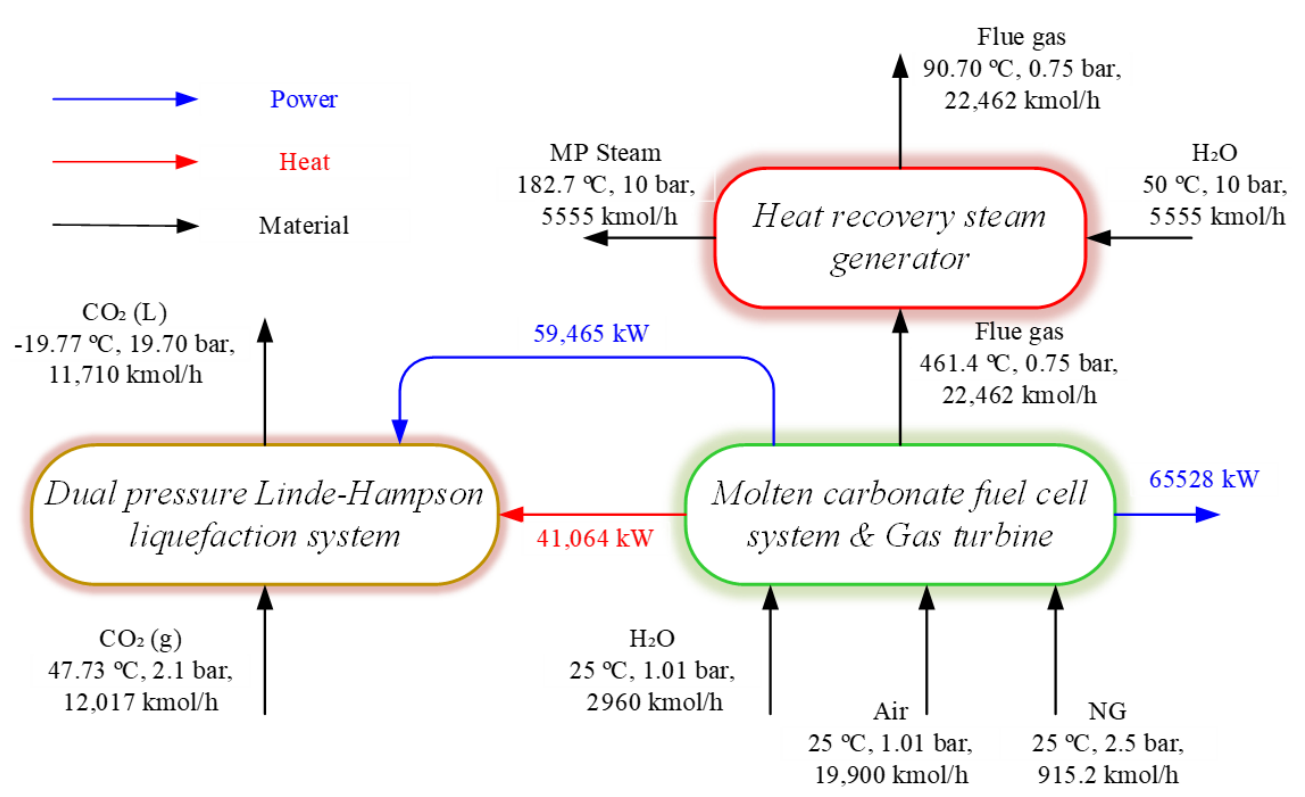

Figure 1. Block diagram of the hybrid system for the tri-generation of liquid carbon dioxide, electricity, and medium pressure steam.

The natural gas (stream A29) at a $25^{\circ} \mathrm{C}$ temperature, 2.5 bar pressure and a $4.202 \mathrm{~kg} / \mathrm{s}$ flow rate is mixed with the A28 steam stream and enters the reformer through stream A31 after it has been preheated in the HX5 heat exchanger by the return stream from the reformer. The required heat for generating the A28 vapor stream is provided by the hightemperature outflow from the $\mathrm{C} 2$ compressor located in the dual pressure Linde-Hampson liquefaction plant. In the reformer, an approximate amount of the methane of stream A31 reacts to produce the hydrogen required for the anode pole reaction. The outflow from the reformer (stream A32) enters the anode pole after transferring heat to the reformer inflow in the HX5 heat exchanger and produces electrons during the reaction with the carbonate ion. The process flow diagram of the combined configuration for the tri-generation of 
liquid carbon dioxide, electricity, and medium pressure steam using the molten carbonate fuel cell, a liquefaction plant, and a HSRG is presented in Figure 2.

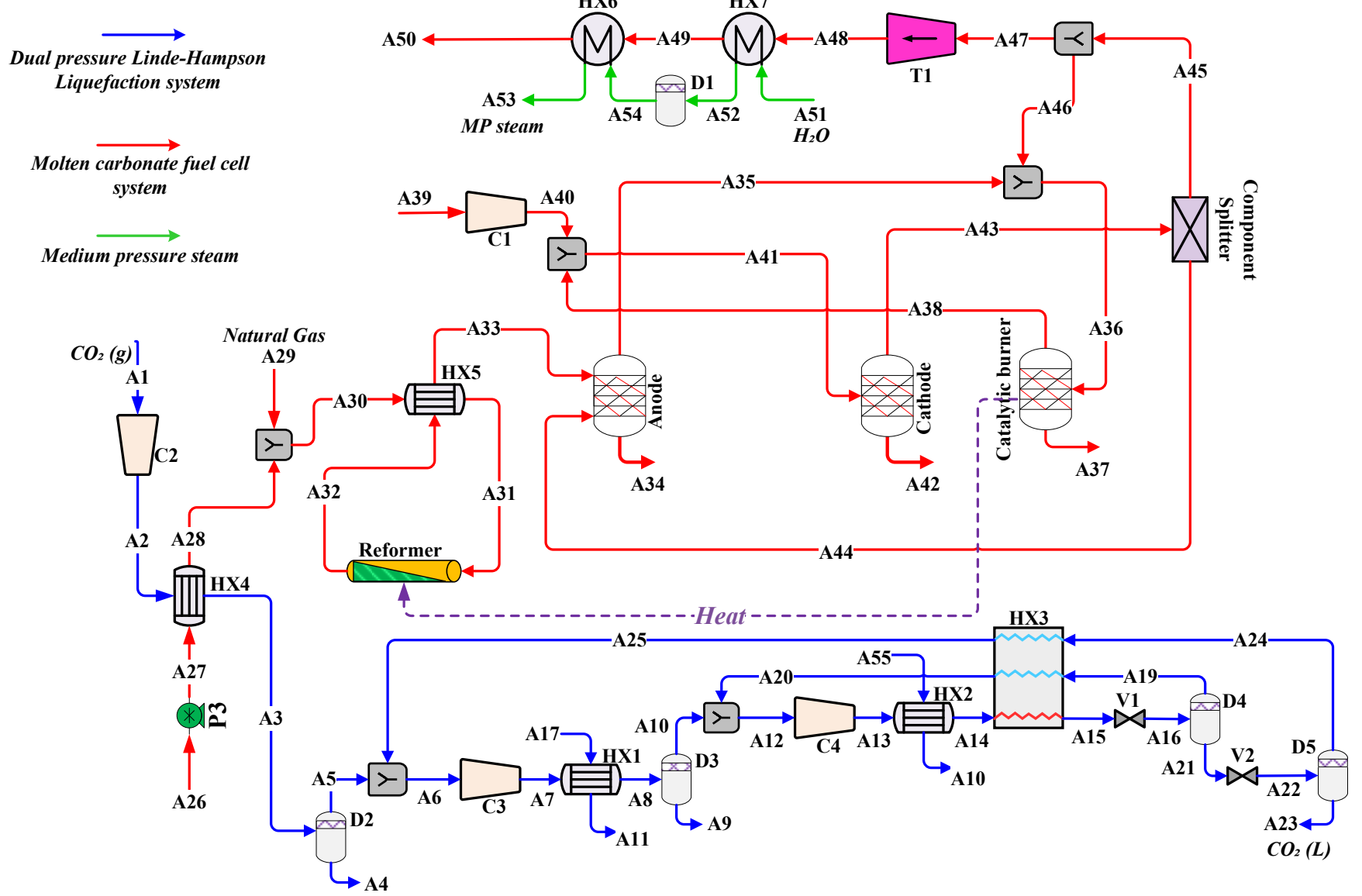

Figure 2. Process flow diagram of the MCFC combined configuration with the liquefaction plant and a HSRG.

The outflow from the anode is mixed with the A4 return flow and enters the catalytic burner through stream A36 so that its entire $\mathrm{CO}$ is converted to $\mathrm{CO}_{2}$. Air is compressed in the $\mathrm{C} 2$ compressor and then it is mixed with the outflow from the catalytic burner and enters the cathode. In the cathode, carbonate ions are produced due to a combination of carbon dioxide and oxygen to maintain the electrolyte concentration. The carbonate ion is carried from the cathode to the anode via the electrolyte. In the integrated structure, the carbonate ion is separated from the cathode outflow with a splitter and enters the anode pole. Part of the fuel cell outflow is used as a return flow to be combined with the outflow from the anode to enter the catalytic burner, and the rest enters the $\mathrm{T} 1$ gas turbine through stream A47 and produces $40.02 \mathrm{MW}$ of electricity.

The A48 outflow of the gas turbine enters the economizer and the evaporator with a temperature of $461.4^{\circ} \mathrm{C}$ to produce $27.8 \mathrm{~kg} / \mathrm{s}$ of steam at the temperature of $182.7^{\circ} \mathrm{C}$ and 10 bar pressure. The outflow from the evaporator then enters the environment at a temperature of $92.22{ }^{\circ} \mathrm{C}$. The reactions that occur at the MCFC are listed below.

- Cathode side reaction [30]:

$$
\mathrm{CO}_{2}+0.5 \mathrm{O}_{2}+2 \mathrm{e}^{-} \rightarrow \mathrm{CO}_{3}^{2-}
$$

- $\quad$ Anode side reaction [11]:

$$
\mathrm{CO}_{3}^{2-}+\mathrm{H}_{2} \rightarrow \mathrm{H}_{2} \mathrm{O}+\mathrm{CO}_{2}+2 \mathrm{e}^{-},
$$


- The overall reaction [31]:

$$
\mathrm{H}_{2}+0.5 \mathrm{O}_{2} \rightarrow \mathrm{H}_{2} \mathrm{O}+\text { Electricity }+ \text { Heat, }
$$

To evaluate the true output voltage of the fuel cell, an appropriate electrochemical modeling of the fuel cell is required [32,33].

$$
\begin{gathered}
V_{\text {cell }}=E_{\text {eq }}-\eta_{\text {act }}-\eta_{\text {conc }}-\eta_{\text {ohm }} \\
E_{\text {eq }}=E_{0}+\frac{R T}{2 F} \ln \left\{\frac{P_{\mathrm{H}_{2}} P_{\mathrm{CO}_{2, c}} \sqrt{P_{\mathrm{O}_{2}}}}{P_{\mathrm{H}_{2} \mathrm{O}} P_{\mathrm{CO}_{2, a}}}\right\} \\
\eta_{\text {an }}=2.27 \times 10^{-9} e^{\left(\frac{E_{\text {act,an }}}{R T}\right)\left(P_{\mathrm{H}_{2}}\right)^{-0.42}\left(P_{\mathrm{CO}_{2}}\right)^{-0.17}\left(P_{\mathrm{H}_{2} \mathrm{O}}\right)^{-1}} \\
\eta_{\text {cat }}=7.505 \times 10^{-10} e^{\left(\frac{E_{\text {act cat }}}{R T}\right)}\left(P_{\mathrm{O}_{2}}\right)^{-0.43}\left(P_{\mathrm{CO}_{2}}\right)^{-0.009}, \\
\eta_{\text {ohm }}=0.5 \times 10^{-4} e^{\left(3016\left(\frac{1}{T}-\frac{1}{923}\right)\right)}, \\
i=\frac{Z n_{e} F}{N A_{\text {cell }}}, \\
P_{M C F C}=\alpha \times N \times A_{\text {cell }} \times i \times V_{\text {cell }},
\end{gathered}
$$

Note that the reformer is applied to convert natural gas to the required hydrogen for the reactions of the molten carbonate fuel cell, so that based on the reactions with steam, $\mathrm{CH}_{4}$ is converted to $\mathrm{CO}_{2}$ and $\mathrm{H}_{2}$ [6].

- Steam reforming reaction:

$$
\mathrm{CH}_{4}+\mathrm{H}_{2} \mathrm{O} \leftrightarrow \mathrm{CO}+3 \mathrm{H}_{2},
$$

- Water-gas shift reaction:

$$
\mathrm{CO}+\mathrm{H}_{2} \mathrm{O} \leftrightarrow \mathrm{CO}_{2}+\mathrm{H}_{2},
$$

- The overall reaction:

$$
\mathrm{CH}_{4}+2 \mathrm{H}_{2} \mathrm{O} \leftrightarrow \mathrm{CO}_{2}+4 \mathrm{H}_{2}
$$

Rxn Heat: $1.647 \times 10^{5} \mathrm{~kJ} / \mathrm{kmol}$.

Information on the structure of the MCFC system is given in [6]. Stream A1, which contains $97 \mathrm{~mol} \%$ of carbon dioxide, enters the $\mathrm{C} 2$ compressor, and its pressure rises by 19.70 bar. Then stream A2 enters the HX4 heat exchanger with a temperature of $281.6^{\circ} \mathrm{C}$ and provides the required heat to the steam entering the reformer. The discharged A3 stream is in a two-phase state and by the D2 flash drum, most of the carbon dioxide impurity is extracted in liquid form. The carbon dioxide flow is mixed with the A25 return stream and enters the C3 compressor through stream A6 at a temperature of $19.73{ }^{\circ} \mathrm{C}$, 19.70 bar pressure, and a $179.6 \mathrm{~kg} / \mathrm{s}$ flow rate, and its pressure increases by 39 bar.

The outflow of the $\mathrm{C} 3$ compressor goes to the HX1 heat exchanger and its temperature is reduced by $32{ }^{\circ} \mathrm{C}$ before it enters the $\mathrm{D} 3$ flash drum. The gas stream extracted from the top of the D3 flash drum is mixed with the A20 return stream and enters the $\mathrm{C} 4$ compressor through stream A12 and its pressure increases by 100 bar. The outflow of the $\mathrm{C} 4$ compressor enters the $\mathrm{HX} 2$ heat exchanger so that its temperature is reduced by $35^{\circ} \mathrm{C}$ before it enters the HX3 heat exchanger and its temperature is reduced by the return cold flow. Stream A15 coming out of the heat exchanger goes to the V1 valve and with a pressure drop of 39 bar, its temperature decreases by $3.323{ }^{\circ} \mathrm{C}$ and stream A16 enters the D4 flash drum. The gas flow coming out of the D4 flash drum is used to chill the HX3 heat exchanger and then as a return flow, it is mixed with the carbon dioxide which has entered the second part. The liquid carbon dioxide outflow of the D4 flash drum goes to the V2 pressure reducing valve and its pressure decreases to 19.70 bar. With the decrease in the pressure, the carbon dioxide flow would be in a two-phase state. Stream A22 enters the D5 flash drum and 
the gas stream coming out of the top of the D5 flash drum is used to cool the HX3 heat exchanger and as a return flow, it blends with the $\mathrm{CO}_{2}$ which has entered the first part. The liquid $\mathrm{CO}_{2}$ flow from the bottom of the D5 flash drum is stored as the final product. More theory and background information on the Linde-Hampson liquefaction plant can be seen in [18].

\section{Exergy Analysis}

Exergy analysis by combining the first and second laws of thermodynamics has become one of the most important instruments for the quantitative and qualitative study of energy consumption in processes. The exergy of an energy source refers to the maximum work achievable when the process of the thermodynamic state identifies its source as dead [34]. The dead state is actually the same ambient conditions that are typically considered to be $25^{\circ} \mathrm{C}$ and $1 \mathrm{~atm}$ pressure. The total exergy rate of a stream can be examined as the sum of the physical exergy and chemical exergy [35]:

$$
e=e^{p h}+e^{c h}
$$

The physical exergy of a stream can be determined as follows [36,37]:

$$
\begin{gathered}
e^{p h}=\left(h-h_{0}\right)-T_{0}\left(s-s_{0}\right), \\
e^{c h}=\sum\left(x_{i} e_{i}^{0}\right)+R T_{0} \sum x_{i} \operatorname{Ln} x_{i} \gamma_{i},
\end{gathered}
$$

where $\gamma$ is the activity coefficient of component $i$, which can be more or less than one, and $e_{i}^{0}$ refers to the standard chemical exergy of any compound in the stream. The exergy balance relation for the control volume of the system is obtained from Equation (17) [38]:

$$
\sum_{i} E x_{i}+\sum_{i}\left(1-\frac{T}{T_{k}}\right) Q_{k}=\sum_{e} E x_{e}+\dot{W}+I
$$

\section{Results and Discussion}

A fuel cell is an electrochemical device that directly turns chemical energy into electrical energy. This conversion continues as long as fuel is injected into the fuel cell [39]. In fact, by eliminating the intermediate stages of energy conversion, fuel cells provide more energy conversion efficiency. In thermal power plants, chemical energy is first turned into heat and then into mechanical energy and finally, the mechanical energy is converted to electrical energy. Each of these stages causes an efficiency loss. Fuel cells do not store energy like a battery; rather, in a fuel cell, a state of energy is converted to another state in a manner that ensures that no material is consumed within the cell. Furthermore, the battery density is lower than the fuel cell, and the process of charging the battery is more sophisticated than filling the fuel tank of the fuel cell. In batteries, the potential of electrochemical conversions decreases after several charges, while in fuel cells there is no such limit. One method of storing energy during off-peak hours is to convert some of the electrical energy into liquid carbon dioxide. On the other hand, during the peak hours of energy consumption, power can be generated by cooling and compressing the liquid carbon dioxide to be used at peak hours. In this paper, molten carbonate fuel cells, the Linde-Hampson liquefaction plant, and a HSRG were used to produce liquid carbon dioxide, electricity, and medium pressure steam. The results of the energy, exergy, and sensitivity examinations of the combined process are presented as follows.

\subsection{Energy Analysis}

This hybrid structure of a molten carbonate fuel cell, a dual pressure Linde-Hampson liquefaction plant, and a HSRG produces $65.53 \mathrm{MW}$ of electricity, $27.80 \mathrm{~kg} / \mathrm{s}$ of medium pressure steam, and $142.9 \mathrm{~kg} / \mathrm{s}$ of liquid $\mathrm{CO}_{2}$. The simulation of the hybrid structure was performed using the HYSYS V10 software and MATLAB V10 programming. Based on the obtained results from the literature, the Peng-Robinson equation of state was 
used for the simulation. The thermodynamic conditions of the streams in the integrated structure of liquid carbon dioxide, electricity, and medium pressure steam production using a molten carbonate fuel cell, a Linde-Hampson liquefaction plant, and a HSRG, are presented in Table 1.

Table 1. The thermodynamic conditions of the streams in the combined process.

\begin{tabular}{|c|c|c|c|c|c|}
\hline Stream & $\begin{array}{c}\text { Temperature } \\
\left({ }^{\circ} \mathrm{C}\right)\end{array}$ & $\begin{array}{l}\text { Pressure } \\
\quad(\mathrm{kPa})\end{array}$ & $\begin{array}{c}\text { Molar Flow } \\
\text { (kmol/h) }\end{array}$ & $\begin{array}{c}\text { Molar } \\
\text { Enthalpy } \\
(\mathrm{kJ} / \mathrm{kmol})\end{array}$ & $\begin{array}{c}\text { Molar Entropy } \\
\left(\mathrm{kJ} / \mathrm{kmol} .{ }^{\circ} \mathrm{C}\right)\end{array}$ \\
\hline A1 & 42.73 & 210.00 & $12,017.56$ & $-388,388.90$ & 169.63 \\
\hline A2 & 281.61 & 1970.00 & $12,017.56$ & $-378,527.46$ & 174.30 \\
\hline A3 & 28.88 & 1970.00 & $12,017.56$ & $-390,828.72$ & 144.16 \\
\hline A4 & 28.88 & 1970.00 & 313.14 & $-286,813.78$ & 55.43 \\
\hline A5 & 28.88 & 1970.00 & $11,704.42$ & $-393,611.49$ & 146.53 \\
\hline A6 & 19.73 & 1970.00 & $14,714.00$ & $-392,930.75$ & 145.10 \\
\hline A7 & 82.41 & 3900.00 & $14,714.00$ & $-390,840.74$ & 146.59 \\
\hline A8 & 32.00 & 3900.00 & $14,714.00$ & $-393,375.22$ & 138.89 \\
\hline A9 & 32.00 & 3900.00 & $14,714.00$ & $-393,375.22$ & 138.89 \\
\hline A10 & 32.00 & 3900.00 & 0.00 & $-287,348.87$ & 56.76 \\
\hline A11 & 30.00 & 100.00 & $95,982.91$ & $-285,832.16$ & 55.00 \\
\hline A12 & 27.32 & 3900.00 & $24,008.48$ & $-390,387.72$ & 138.07 \\
\hline A13 & 118.32 & $10,000.00$ & $24,008.48$ & $-387,688.10$ & 139.82 \\
\hline A14 & 35.00 & $10,000.00$ & $24,008.48$ & $-397,444.87$ & 110.76 \\
\hline A15 & 33.00 & $10,000.00$ & $24,008.48$ & $-397,858.95$ & 109.41 \\
\hline A16 & 3.32 & 3900.00 & $24,008.48$ & $-397,858.95$ & 111.32 \\
\hline A17 & 25.00 & 100.00 & $95,982.91$ & $-286,220.69$ & 53.70 \\
\hline A18 & 30.00 & 100.00 & $602,898.75$ & $-285,832.16$ & 55.00 \\
\hline A19 & 3.32 & 3900.00 & 9288.61 & $-386,666.14$ & 133.00 \\
\hline A20 & 20.00 & 3900.00 & 9288.61 & $-385,630.58$ & 136.64 \\
\hline A21 & 3.32 & 3900.00 & $14,719.87$ & $-404,921.90$ & 97.64 \\
\hline A22 & -19.77 & 1970.00 & $14,719.87$ & $-404,921.90$ & 98.45 \\
\hline A23 & -19.77 & 1970.00 & $11,710.08$ & $-408,656.72$ & 88.17 \\
\hline A24 & -19.77 & 1970.00 & 3009.79 & $-390,390.94$ & 138.44 \\
\hline A25 & -17.52 & 1970.00 & 3009.79 & $-390,283.73$ & 138.87 \\
\hline A26 & 25.00 & 101.00 & 2960.00 & $-286,355.93$ & 53.30 \\
\hline A27 & 25.01 & 250.00 & 2960.00 & $-286,352.60$ & 53.30 \\
\hline A28 & 186.85 & 250.00 & 2960.00 & $-236,409.66$ & 180.79 \\
\hline A29 & 25.00 & 250.00 & 915.20 & $-72,323.31$ & 176.10 \\
\hline A30 & 145.36 & 250.00 & 3875.20 & $-197,657.64$ & 184.79 \\
\hline A31 & 298.00 & 250.00 & 3875.20 & $-191,866.78$ & 196.56 \\
\hline A32 & 550.00 & 238.86 & 4107.87 & $-165,674.83$ & 208.40 \\
\hline A33 & 420.16 & 250.00 & 4107.87 & $-171,137.70$ & 200.81 \\
\hline
\end{tabular}


Table 1. Cont.

\begin{tabular}{cccccc}
\hline Stream & $\begin{array}{c}\text { Temperature } \\
\left({ }^{\circ} \mathbf{C}\right)\end{array}$ & $\begin{array}{c}\text { Pressure } \\
\mathbf{( k P a )}\end{array}$ & $\begin{array}{c}\text { Molar Flow } \\
\mathbf{( k m o l / h )}\end{array}$ & $\begin{array}{c}\text { Molar } \\
\text { Enthalpy } \\
\mathbf{( k J / k m o l )}\end{array}$ & $\begin{array}{c}\text { Molar Entropy } \\
\left.\mathbf{( k J / k m o l .}{ }^{\circ} \mathbf{C}\right)\end{array}$ \\
\hline A34 & 661.63 & 250.00 & 0.00 & $-37,096.93$ & 275.99 \\
\hline A35 & 661.63 & 250.00 & $24,068.18$ & $-37,097.14$ & 275.99 \\
\hline A37 & 667.89 & 250.00 & 0.00 & $-31,504.55$ & 191.26 \\
\hline A39 & 25.00 & 101.40 & $19,900.00$ & -6.81 & 151.69 \\
\hline A40 & 133.10 & 250.00 & $19,900.00$ & 3180.72 & 153.30 \\
\hline A42 & 650.60 & 250.00 & 0.00 & $-30,992.08$ & 190.53 \\
\hline A44 & 650.00 & 250.00 & $19,458.98$ & $-10,217.62$ & 293.08 \\
\hline A47 & 650.23 & 250.00 & $22,462.82$ & $-31,313.37$ & 188.33 \\
\hline A48 & 461.39 & 75.00 & $22,462.82$ & $-37,726.61$ & 190.59 \\
\hline A49 & 170.90 & 75.00 & $22,462.82$ & $-47,021.89$ & 174.53 \\
\hline A50 & 92.22 & 75.00 & $22,462.82$ & $-49,445.03$ & 168.52 \\
\hline A51 & 50.00 & 1000.00 & 5555.34 & $-284,341.99$ & 59.72 \\
\hline A52 & 169.80 & 1000.00 & 5555.34 & $-274,544.09$ & 85.46 \\
\hline A53 & 182.70 & 1000.00 & 5555.34 & $-236,958.95$ & 168.36 \\
\hline A54 & 169.80 & 1000.00 & 5555.34 & $-274,544.09$ & 85.46 \\
\hline A55 & 25.00 & 100.00 & $602,898.75$ & $-286,220.69$ & 53.70 \\
\hline
\end{tabular}

The validation of the several parameters of the Linde-Hampson liquefaction cycle in this paper with reference [18] is illustrated in Figure 3. The results of the simulation analysis with the HYSYS software show that the fuel cell performance coefficient, total cooling duty, and refrigeration energy differ from the evaluated values reported in the reference article by $2.07 \%, 0.604 \%$, and $2.022 \%$, respectively. This indicates that the simulation results are acceptable.

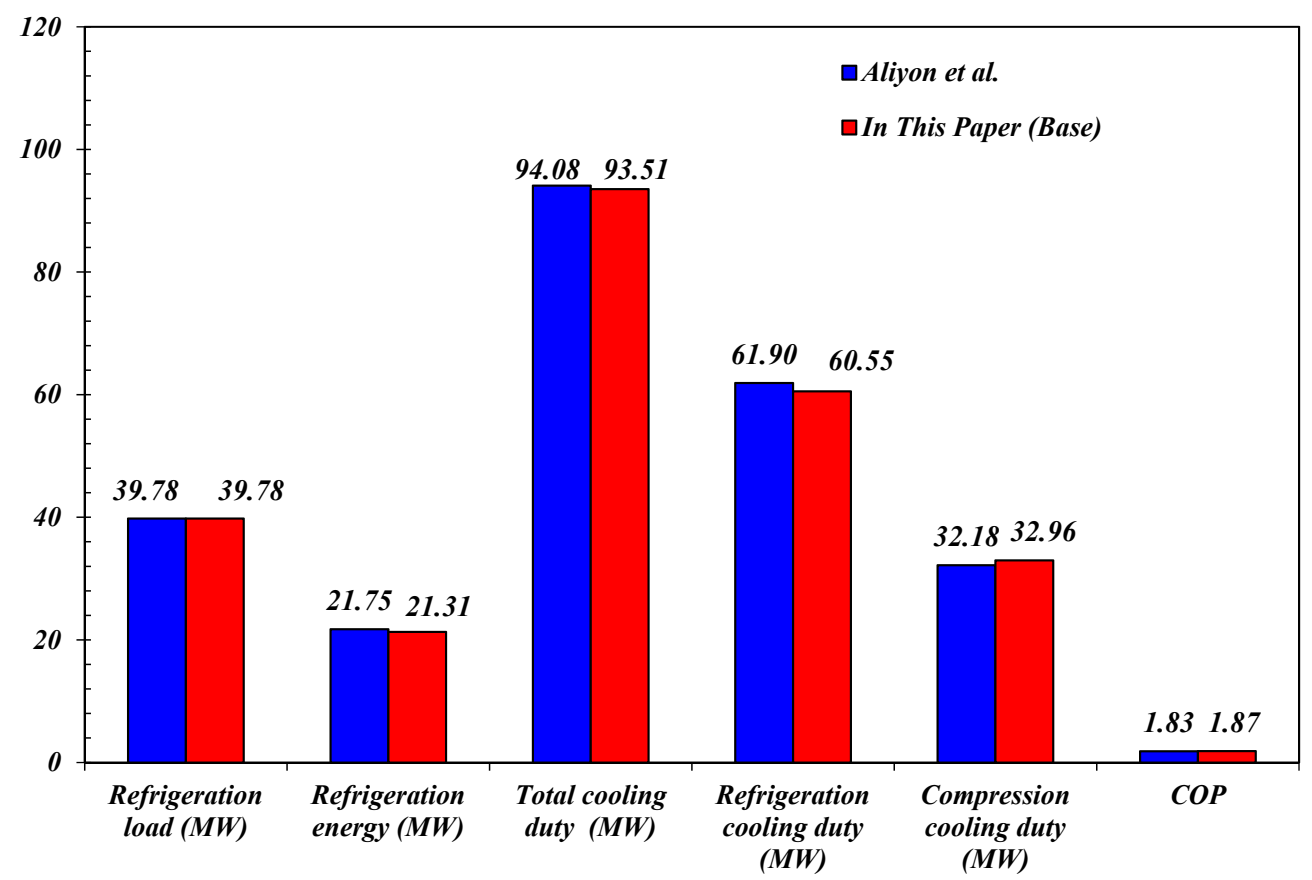

Figure 3. Validation of the process developed for the dual pressure Linde-Hampson liquefaction plant through a comparison of results of this system and the data in [18]. 
Figure 4 shows the voltage variations in the current density change of the current density in the MCFC for this integrated structure and in [6]. The temperature and pressure of the fuel cell in the validation were considered to be $650{ }^{\circ} \mathrm{C}$ and 1 bar, respectively. The results of the validation show that the simulated fuel cell in this study is in an appropriate agreement with the one reported in [6]. To achieve the optimal design, it is necessary to evaluate the influence of each variable in the fuel cell system on its performance by sensitivity analysis.

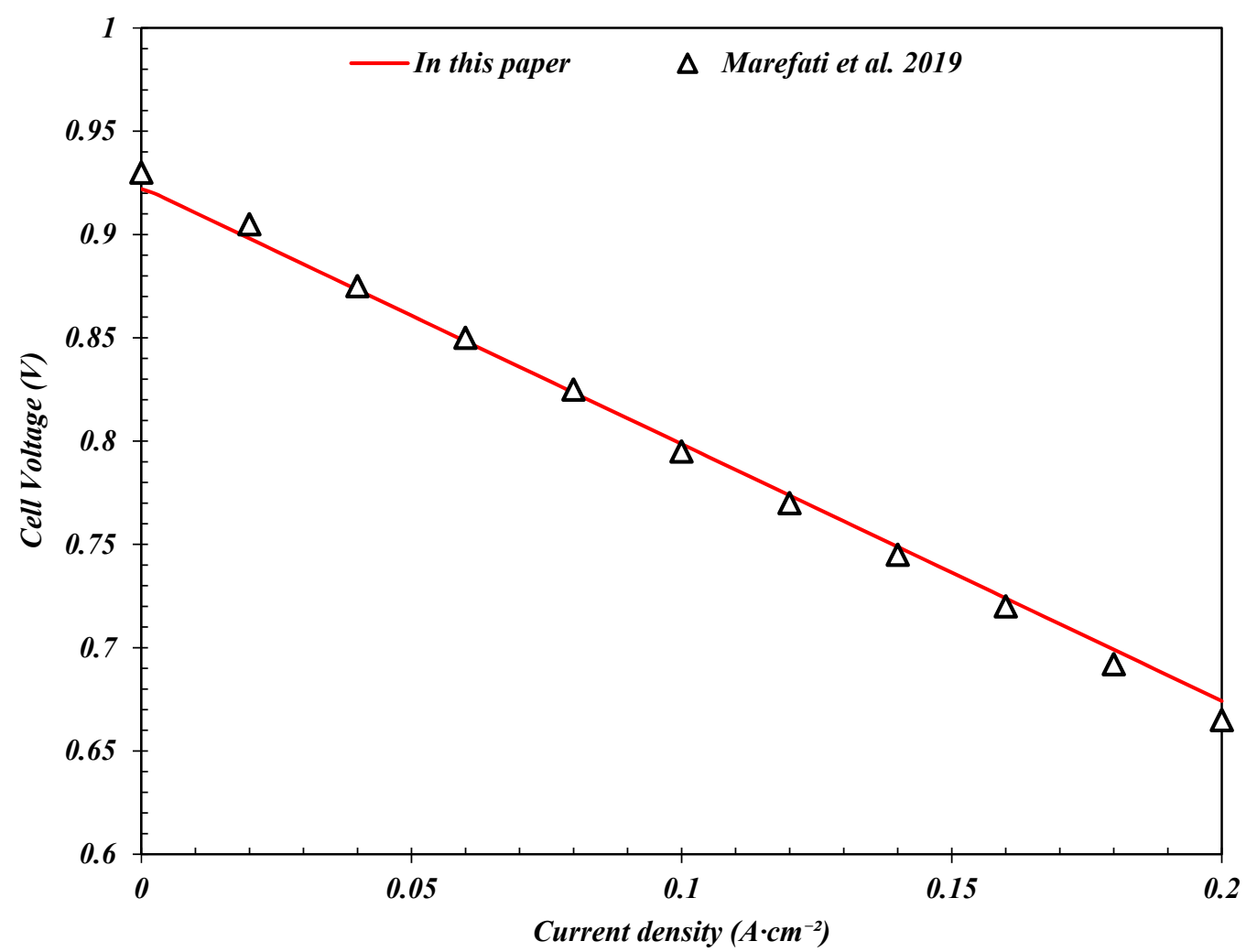

Figure 4. The voltage variation with the current density change of the current density in the MCFC for this integrated structure and in [6].

Figure 5 shows the variations in power density, voltage, and efficiency of the fuel cell with the variation of current density in the operating conditions of the fuel cell used in the combined system. The design temperature and pressure of the fuel cell were $650{ }^{\circ} \mathrm{C}$ and 2.5 bar, respectively. The rate of voltage drop due to mass transfer and activation increased with the increase in current density.

As the current density increases, the cell voltage decreases due to irreversible losses. The power density rises with the increment in current density till it reaches a maximum value and then it starts to decrease. As the current density increases, the cell efficiency decreases due to the irreversible losses, and as a result, less of the generated heat is converted into electricity by the electrochemical reaction, and the rest is released as waste heat. This phenomenon leads to a reduction in power production and therefore, more air is needed to remove the excessive heat from the cell to cool it.

The inlet airflow to the cathode has an important impact on the regulation of the cell temperature, the size of the fuel cell unit, and the electricity consumption in the gears. The operational specifications of the fuel cell utilized in the hybrid process of producing liquid carbon dioxide, electricity, and medium pressure steam are presented in Table 2. The current density, fuel utilization, and cell voltage in the molten carbonate fuel cell were $0.2000 \mathrm{~A} \cdot \mathrm{cm}^{-2}, 0.6800$, and $0.7917 \mathrm{~V}$, respectively. The results of the simulation of the hybrid process for the tri-generation of electricity, medium pressure steam, and liquid $\mathrm{CO}_{2}$ are presented in Table 3. 


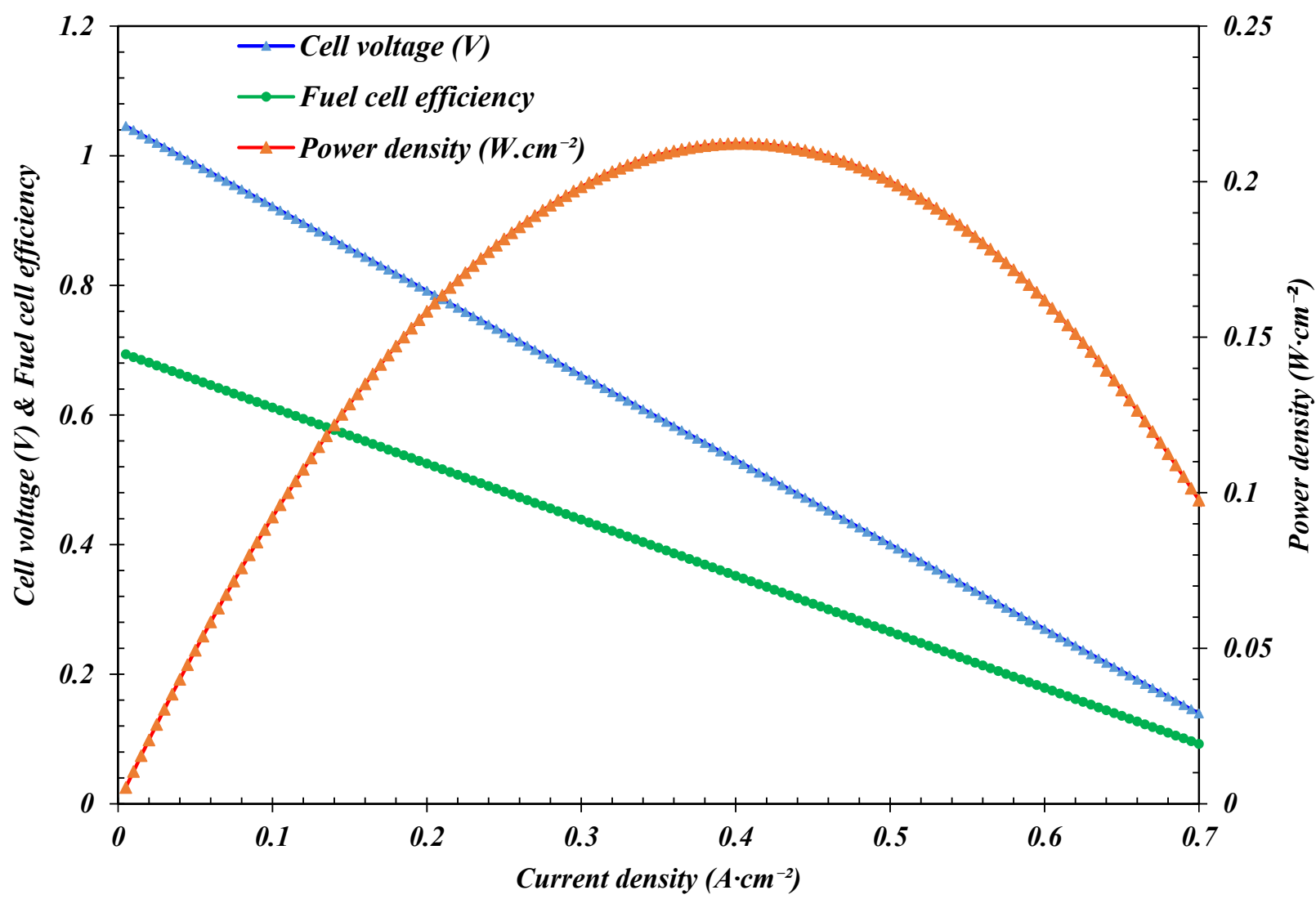

Figure 5. The variations in power density, voltage, and efficiency of the fuel cell with the variation of fuel cell current density in the operating conditions of the fuel cell.

Table 2. The operational specifications of the fuel cell utilized in the combined configuration.

\begin{tabular}{cc}
\hline Parameter & Value \\
\hline Current density A.cm ${ }^{-2}$ & 0.2000 \\
\hline Fuel utilization & 0.6800 \\
\hline Cell voltage $(\mathrm{V})$ & 0.7917 \\
\hline Total power produced $(\mathrm{MW})$ & 102.6 \\
\hline Effective area per cell $\left(\mathrm{m}^{2}\right)$ & 0.7500 \\
\hline Cell number & 88,159 \\
\hline Fuel cell operating temperature $\left({ }^{\circ} \mathrm{C}\right)$ & 650.0 \\
\hline Fuel cell operating pressure $(\mathrm{bar})$ & 2.500 \\
\hline Fuel flow rate $(\mathrm{kmol} / \mathrm{h})$ & 915.2 \\
\hline Ambient temperature fuel cell $\left({ }^{\circ} \mathrm{C}\right)$ & 25.00 \\
\hline Ambient pressure fuel cell $(\mathrm{bar})$ & 1.000 \\
\hline LHV of fuel $(\mathrm{kJ} / \mathrm{kg})$ & 46,837 \\
\hline Inverter efficiency & 0.98 \\
\hline
\end{tabular}

The MCFC cycle and the net overall thermal and overall thermal efficiencies of the developed combined configuration are $52.13 \%, 63.43 \%$, and $82.21 \%$, respectively. The simulation results reveal that the coefficient of performance and refrigeration energy in the dual pressure Linde-Hampson liquefaction plant is 1.866 and $26.54 \mathrm{MW}$, respectively. 
Table 3. The results of the simulation of the combined configuration for tri-generation of electricity, medium pressure steam, and liquid $\mathrm{CO}_{2}$.

\begin{tabular}{|c|c|}
\hline Parameters & Value \\
\hline Refrigeration load (MW) & 49.55 \\
\hline Refrigeration energy (MW) & 26.54 \\
\hline Total cooling duty (MW) & 116.4 \\
\hline Refrigeration cooling duty (MW) & 75.42 \\
\hline Compression cooling duty (MW) & 41.06 \\
\hline $\mathrm{COP}$ & 1.866 \\
\hline Power produced (MW) & 77.08 \\
\hline Power consumption (MW) & 142.6 \\
\hline Net power output (MW) & 65.52 \\
\hline MCFC cycle efficiency (HHV Base) & $\eta_{M C F C, H H V}=\frac{\dot{W}_{M C F C, A C}}{\dot{m}_{\text {fuel, anode }} \times H H V_{\text {fuel,anode }}}=0.4694$ \\
\hline MCFC cycle efficiency (LHV Base) & $\eta_{M C F C, L H V}=\frac{\dot{W}_{M C F C, A C}}{\dot{m}_{\text {fuel, anode }} \times L H V_{\text {fuel, anode }}}=0.5213$ \\
\hline Electrical efficiency (HHV Base) & $\eta_{\text {Electrical }, H H V}=\frac{\dot{W}_{M C F C, A C}+\dot{W}_{G T}-\dot{W}_{\text {Compressor } 1}-\dot{W}_{\text {Pump } 1}}{\dot{m}_{\text {fuel }} \times H H V_{\text {fuel }}}=0.2998$ \\
\hline Electrical efficiency(LHV Base) & $\eta_{\text {Electrical }, L H V}=\frac{\dot{W}_{M C F C, A C}+\dot{W}_{G T}-\dot{W}_{\text {Compressor } 1}-\dot{W}_{\text {Pump } 1}}{\dot{m}_{\text {fuel }} \times L H V_{\text {fuel }}}=0.3330$ \\
\hline Net overall thermal efficiency (HHV Base) & $\eta_{\text {thermal }, H H V}=\frac{\dot{W}_{M C F C, A C}+\dot{Q}_{H R S G}+\dot{W}_{G T}-\dot{W}_{\text {Compressor } 1,2,3,4}+\dot{W}_{\text {Pump } 1}}{\dot{m}_{f u e l} \times H H V_{f u e l}}=0.6343$ \\
\hline Net overall thermal efficiency (LHV Base) & $\eta_{\text {thermal }, L H V}=\frac{\dot{W}_{M C F C, A C}++\dot{Q}_{H R S G}+\dot{W}_{G T}-\dot{W}_{\text {Compressor } 1,2,3,4}+\dot{W}_{\text {Pump } 1}}{\dot{m}_{f u e l} \times L H V_{\text {fuel }}}=0.7045$ \\
\hline Overall thermal efficiency (HHV Base) & $\begin{array}{c}\eta_{\text {thermal }, H H V}= \\
\frac{\dot{W}_{M C F C, A C}+\dot{Q}_{H R S G}+\dot{W}_{G T}+\dot{W}_{\text {equal, refrigeration }}-\dot{W}_{\text {Compressor } 1,2,3,4}+\dot{W}_{\text {Pump } 1}}{\dot{m}_{\text {fuel }} \times H H V_{\text {fuel }}}=0.8221\end{array}$ \\
\hline Overall thermal efficiency (LHV Base) & $\begin{array}{c}\eta_{\text {thermal }, L H V}= \\
\frac{\dot{W}_{M C F C, A C}+\dot{Q}_{H R S G}+\dot{W}_{G T}+\dot{W}_{\text {equal, refrigeration }}-\dot{W}_{\text {Compressor } 1,2,3,4}+\dot{W}_{\text {Pump } 1}}{\dot{m}_{\text {fuel }} \times L H V_{\text {fuel }}}=0.9132\end{array}$ \\
\hline
\end{tabular}

\subsection{Exergy Analysis}

The exergy assessment of the combined process was performed by the relationship between the HYSYS package and MATLAB programming. The output of the exergy analysis of the processes including the physical, chemical, and total exergy of the streams are listed in Table 4.

The equations used for the exergy analysis of the integrated structure are presented in Appendix A. The input and output exergy, the exergy degradation, and the efficiency of the implemented devices in the combined process for the tri-generation of liquid carbon dioxide, electricity, and medium pressure steam are presented in Table 5.

For the exergy analysis, the performance of each part of the equipment should be evaluated from the irreversibility and exergy yield points of view. The simulation results show that the exergy yield of the valves is lower than other devices, while they had less irreversibility. Among the expansion valves, the V2 valve with $67.43 \%$ efficiency has the highest exergy yield and the V1 valve with $53.17 \%$ efficiency has the lowest exergy yield. Among the heat exchangers, the HX5 exchanger with $80.85 \%$ efficiency has the lowest exergy efficiency and the HX4 exchanger with $96.95 \%$ efficiency has the highest exergy efficiency. Among the heat exchangers, the HX6 exchanger has the highest exergy destruction with a magnitude of $8.258 \mathrm{MW}$, and the HX3 exchanger has the lowest exergy destruction with a magnitude of $0.2251 \mathrm{MW}$. Among the compressors of the developed 
hybrid process, the $\mathrm{C} 3$ compressor with $78.71 \%$ efficiency has the lowest exergy efficiency and the $\mathrm{C} 2$ compressor with $85.87 \%$ efficiency has the highest exergy yield.

Table 4. The output of exergy assessment of processes including physical, chemical, and total exergy of the streams.

\begin{tabular}{|c|c|c|c|c|c|c|c|}
\hline Stream & $\begin{array}{c}\text { Physical } \\
\text { Exergy } \\
(\mathrm{kW})\end{array}$ & $\begin{array}{c}\text { Chemical } \\
\text { Exergy } \\
(\mathbf{k W})\end{array}$ & $\begin{array}{c}\text { Total Exergy } \\
(\mathbf{k W})\end{array}$ & Stream & $\begin{array}{c}\text { Physical } \\
\text { Exergy } \\
(\mathbf{k W})\end{array}$ & $\begin{array}{c}\text { Chemical } \\
\text { Exergy } \\
(\mathbf{k W})\end{array}$ & $\begin{array}{c}\text { Total Exergy } \\
(\mathbf{k W})\end{array}$ \\
\hline A1 & 6045.04 & $65,700.40$ & $71,745.43$ & A29 & 567.63 & $205,008.79$ & $205,576.42$ \\
\hline A2 & $34,312.96$ & $65,700.40$ & $100,013.36$ & A30 & 8760.19 & $214,618.18$ & $223,378.36$ \\
\hline A3 & $23,252.71$ & $65,700.40$ & $88,953.11$ & A31 & $11,215.69$ & $214,618.18$ & $225,833.86$ \\
\hline A4 & 7.10 & 287.74 & 294.84 & A32 & $17,143.70$ & $217,458.03$ & $234,601.74$ \\
\hline A5 & $23,067.53$ & $65,590.74$ & $88,658.27$ & A33 & $13,494.40$ & $217,458.03$ & $230,952.43$ \\
\hline A6 & $29,008.98$ & $82,087.87$ & $111,096.85$ & A34 & 0.00 & 0.00 & 0.00 \\
\hline A7 & $35,732.66$ & $82,087.87$ & $117,820.53$ & A35 & $480,837.44$ & $543,858.18$ & $1,024,695.62$ \\
\hline A8 & $34,755.32$ & $82,087.87$ & $116,843.20$ & A36 & $4,743,988.53$ & $1,499,694.60$ & $6,243,683.13$ \\
\hline A9 & $34,755.32$ & $82,087.87$ & $116,843.20$ & A37 & 0.00 & 0.00 & 0.00 \\
\hline A11 & 84.83 & $83,185.94$ & $83,270.77$ & A39 & 10.14 & 890.09 & 900.23 \\
\hline A12 & $56,731.74$ & $132,451.37$ & $189,183.12$ & $\mathrm{~A} 40$ & $14,973.28$ & 890.09 & $15,863.37$ \\
\hline A13 & $71,258.19$ & $132,451.37$ & $203,709.57$ & A41 & $4,878,913.39$ & $1,311,478.75$ & $6,190,392.14$ \\
\hline A14 & $63,981.57$ & $132,451.37$ & $196,432.95$ & A42 & 0.00 & 0.00 & 0.00 \\
\hline A15 & $63,900.36$ & $132,451.37$ & $196,351.73$ & A43 & $4,815,855.29$ & $1,334,215.12$ & $6,150,070.42$ \\
\hline A16 & $60,094.07$ & $132,451.37$ & $192,545.45$ & A44 & $489,176.71$ & $347,886.25$ & $837,062.96$ \\
\hline A17 & 0.00 & $83,185.94$ & $83,185.94$ & A45 & $4,395,835.95$ & $986,358.85$ & $5,382,194.81$ \\
\hline A18 & 532.84 & $522,516.96$ & $523,049.80$ & A46 & $4,319,744.56$ & $969,938.28$ & $5,289,682.84$ \\
\hline A19 & $22,112.02$ & $50,412.58$ & $72,524.61$ & A 47 & $76,706.44$ & $17,223.36$ & $93,929.80$ \\
\hline A20 & $21,983.43$ & $50,412.58$ & $72,396.02$ & A 48 & $32,488.03$ & $17,223.36$ & $49,711.39$ \\
\hline A21 & $37,895.56$ & $82,125.28$ & $120,020.84$ & A49 & 4373.94 & $17,223.36$ & $21,597.30$ \\
\hline A22 & $36,914.12$ & $82,125.28$ & $119,039.40$ & A50 & 424.45 & $17,223.36$ & $17,647.81$ \\
\hline A23 & $30,795.33$ & $65,627.51$ & $96,422.84$ & A51 & 155.39 & $18,070.33$ & $18,225.73$ \\
\hline A24 & 6079.95 & $16,536.61$ & $22,616.55$ & A52 & 3428.85 & $18,070.33$ & $21,499.19$ \\
\hline A25 & 6064.56 & $16,536.61$ & $22,601.17$ & A53 & $23,284.33$ & $18,070.33$ & $41,354.67$ \\
\hline A26 & 0.00 & 9628.25 & 9628.25 & A54 & 3428.85 & $18,070.33$ & $21,499.19$ \\
\hline A27 & 2.92 & 9628.25 & 9631.17 & A55 & 0.00 & $522,512.25$ & $522,512.25$ \\
\hline A28 & 9811.20 & 9628.25 & $19,439.44$ & & & & \\
\hline
\end{tabular}

Moreover, among the compressors, the $\mathrm{C} 2$ compressor has the highest exergy destruction with 4.651 MW and the C3 compressor has the lowest exergy destruction with 1.818 MW. The contribution of exergy destruction of each piece of equipment in the combined process is depicted in Figure 6 separately. The results show that compared to other equipment, the MCFC, heat exchangers, and compressors utilized in the combined process have the most exergy destruction with a share of $37.72 \%, 18.71 \%$, and $12.26 \%$, respectively. The total exergy efficiency and exergy destruction of the entire combined process is $73.18 \%$ and 102.7 MW, respectively. 
Table 5. The input and output exergy, exergy degradation, and efficiency of implemented devices in the combined process.

\begin{tabular}{|c|c|c|c|c|}
\hline Components & $\dot{\mathbf{X}}_{\text {Fuel }}(\mathrm{MW})$ & $\dot{\mathbf{X}}_{\text {Prod }}(\mathbf{M W})$ & $\dot{\mathbf{X}}_{\text {Des }}(\mathbf{M W})$ & Efficiency \\
\hline HX1 & 201.0 & 200.1 & 0.891 & 0.9139 \\
\hline HX2 & 726.2 & 719.4 & 6.739 & 0.8964 \\
\hline HX3 & 291.5 & 291.3 & 0.225 & 0.9185 \\
\hline HX4 & 109.6 & 108.3 & 1.251 & 0.9695 \\
\hline HX5 & 457.9 & 456.7 & 1.193 & 0.8085 \\
\hline HX6 & 71.2 & 62.95 & 8.258 & 0.8576 \\
\hline HX7 & 39.8 & 39.14 & 0.676 & 0.9553 \\
\hline $\mathrm{T} 1$ & 93.92 & 89.72 & 4.201 & 0.9050 \\
\hline $\mathrm{C} 1$ & 18.52 & 15.86 & 2.656 & 0.8492 \\
\hline $\mathrm{C} 2$ & 104.6 & 100.0 & 4.651 & 0.8587 \\
\hline $\mathrm{C} 3$ & 119.6 & 117.8 & 1.818 & 0.7871 \\
\hline $\mathrm{C} 4$ & 207.1 & 203.7 & 3.477 & 0.8069 \\
\hline P1 & 9.630 & 9.631 & 0 & 0.9706 \\
\hline MCFC & 246.8 & 208.0 & 38.768 & 0.8429 \\
\hline Reformer & 237.3 & 234.6 & 2.749 & 0.9884 \\
\hline V1 & 196.3 & 192.5 & 3.806 & 0.5317 \\
\hline $\mathrm{V} 2$ & 120.0 & 119.0 & 0.9814 & 0.6743 \\
\hline D1 & 21.49 & 21.49 & 0.00 & 1.0000 \\
\hline D2 & 88.95 & 88.95 & 0.00 & 1.0000 \\
\hline D3 & 116.8 & 116.8 & 0.00 & 1.0000 \\
\hline D4 & 192.5 & 192.5 & 0.00 & 1.0000 \\
\hline D5 & 119.0 & 119.0 & 0.00 & 1.0000 \\
\hline Cycle & 383.1 & 280.3 & 102.7 & 0.7318 \\
\hline
\end{tabular}

\subsection{Sensitivity Analysis}

With the sensitivity study, important and influential parameters of the combined system of liquid carbon dioxide, electricity, and medium pressure steam production using a molten carbonate fuel cell, a Linde-Hampson double-effect refrigeration system, and a HSRG were identified and investigated and their behavior in regard to these changes was studied. Figure 7 shows the variation of the refrigeration cycle performance coefficient and the refrigeration cooling duty with the reduction in the outlet pressure of the V1 expansion valve. The results of the sensitivity analysis show that when the outlet pressure of the V1 expansion valve was increased from 39 bar to 45 bar, the amount of steam coming out of the D4 flash drum (in other words, the return flow of carbon dioxide) decreased, and as a result, the refrigeration cooling duty increased by $0.7165 \%$ and the refrigeration cycle performance coefficient was reduced by $9.654 \%$. 


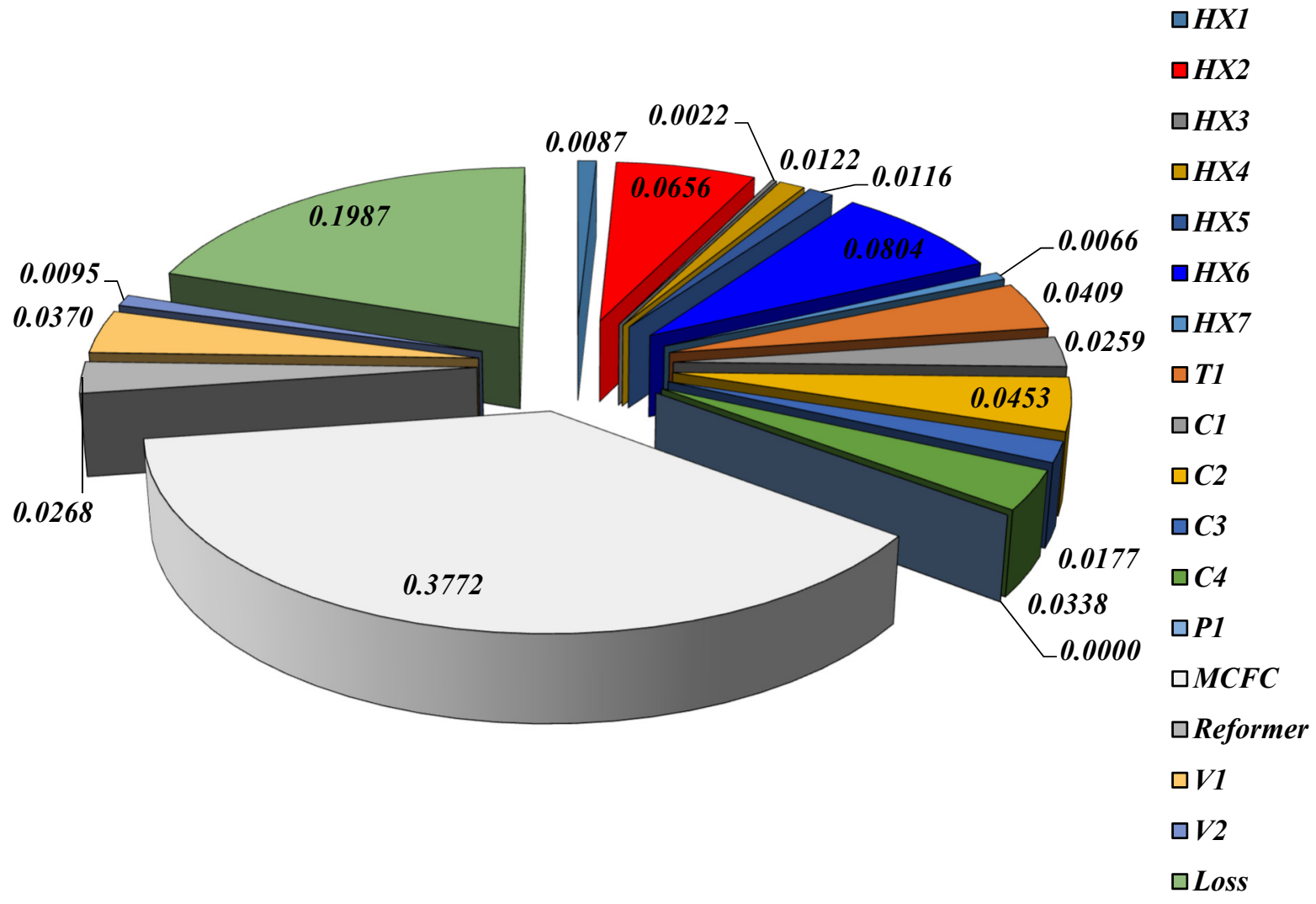

(a)

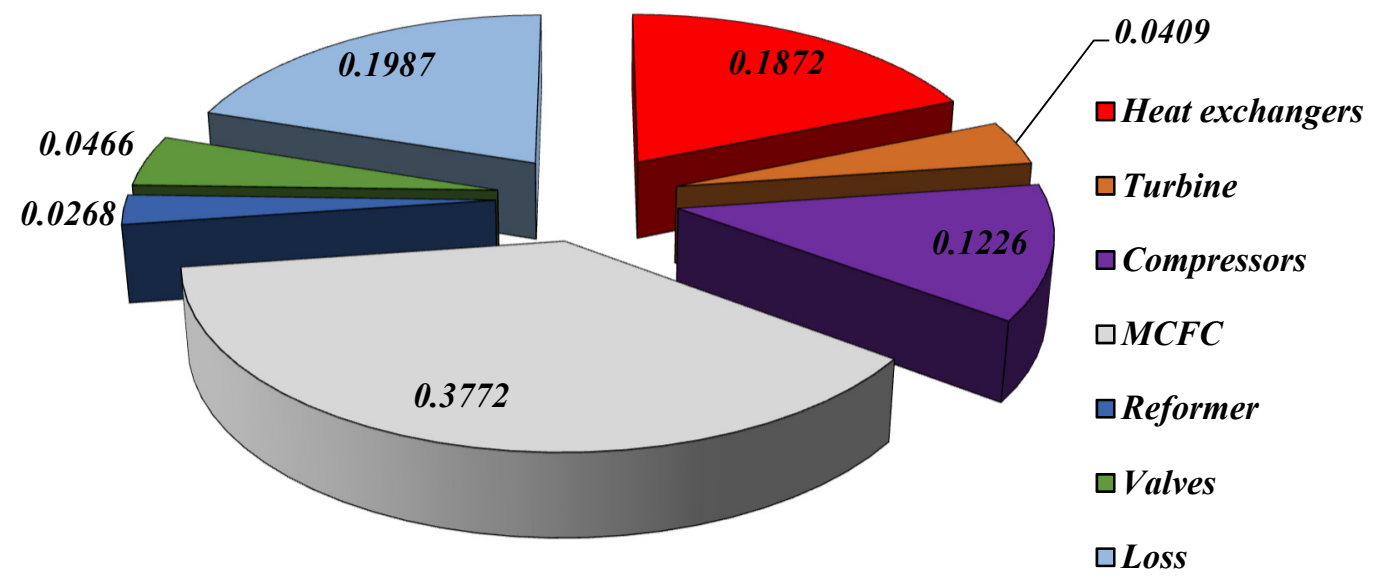

(b)

Figure 6. The contribution of exergy destruction of each device in the hybrid process. (a) Exergy destruction of different devices. (b) Exergy destruction in the integrated unit. 


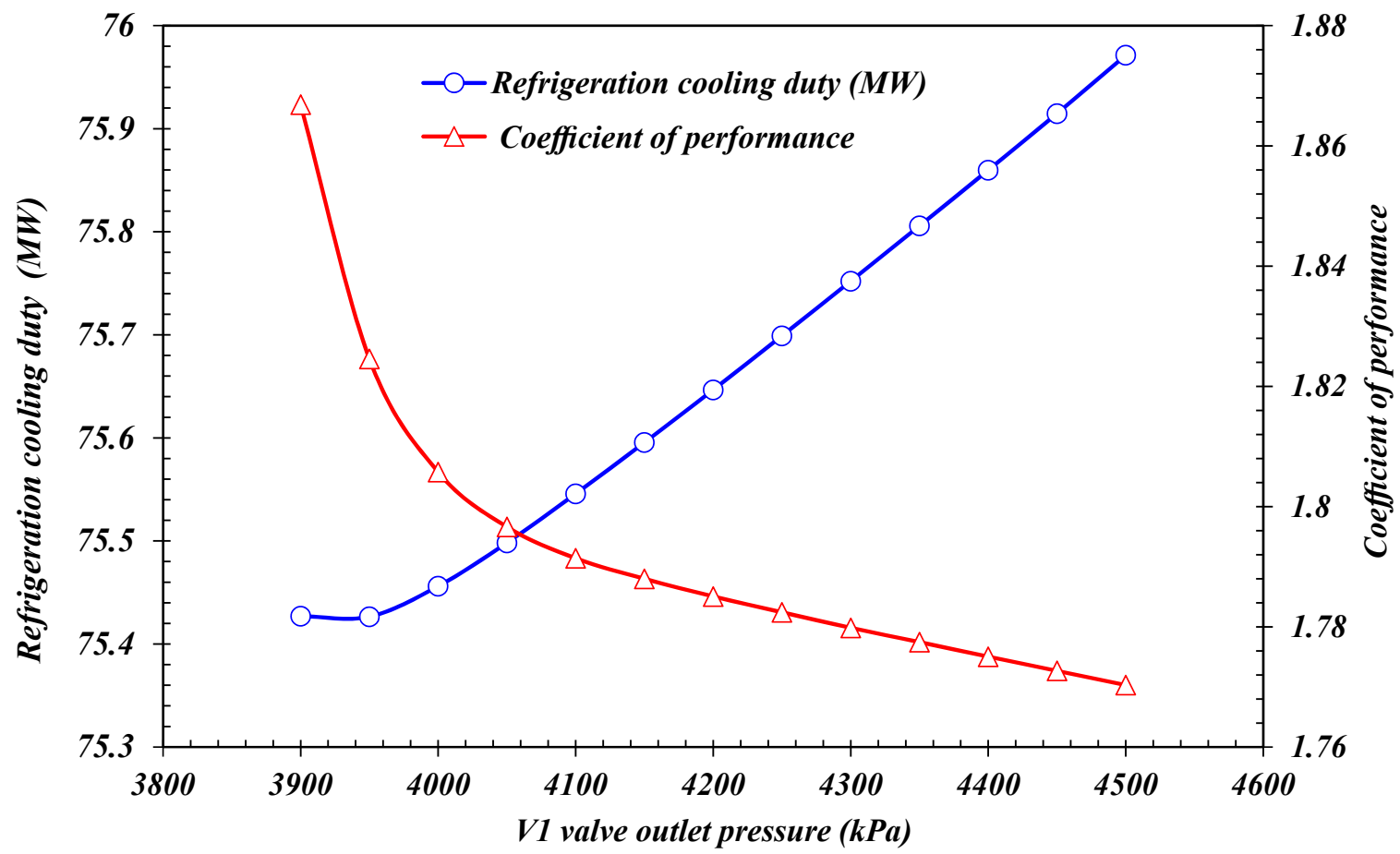

Figure 7. The variation of the refrigeration cycle performance coefficient and refrigeration cooling duty with the reduction in the outlet pressure of the V1 expansion valve.

The changes in the refrigeration load and the refrigeration energy with the reduction in the outlet pressure of the V1 expansion valve are presented in Figure 8. The results of the sensitivity analysis show that when the outlet pressure of the V1 expansion valve was increased from 39 bar to 45 bar, the amount of refrigeration energy in the refrigeration cycle increased by $2.151 \%$. Moreover, by increasing the outlet pressure of the V1 expansion valve to 41 bar, the amount of the refrigeration load decreased and then increased to 45 bar.

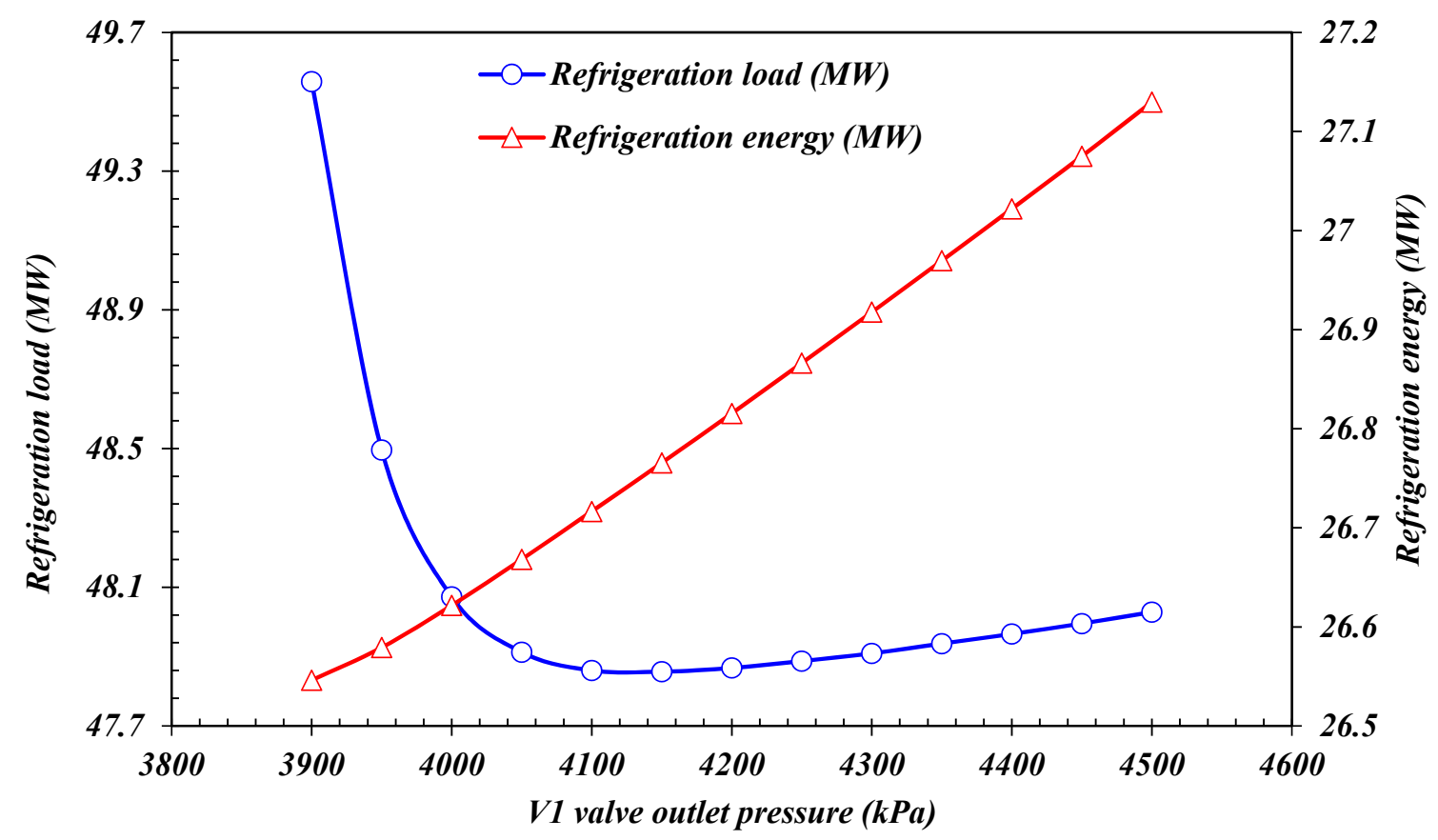

Figure 8. The changes in refrigeration load and refrigeration energy with the reduction in outlet pressure of the V1 expansion valve. 
Figure 9 shows the changes in electricity produced by the fuel cell and electrical efficiency with the reduction in fuel input to the fuel cell. The output illustrates that when fuel input to the fuel cell increased, the electricity generated by the fuel cell and electrical efficiency increased from $89.68 \mathrm{MW}$ and $29.06 \%$ to $134.5 \mathrm{MW}$ and $37.75 \%$, respectively. The variation of the net overall thermal efficiency and the overall exergy efficiency with respect to the reduction in fuel input to the fuel cell is depicted in Figure 10. The output illustrates that when the fuel input to the fuel cell increased, the net overall thermal efficiency in the integrated structure increased by $18.09 \%$, and the overall exergy efficiency decreased by $12.95 \%$.

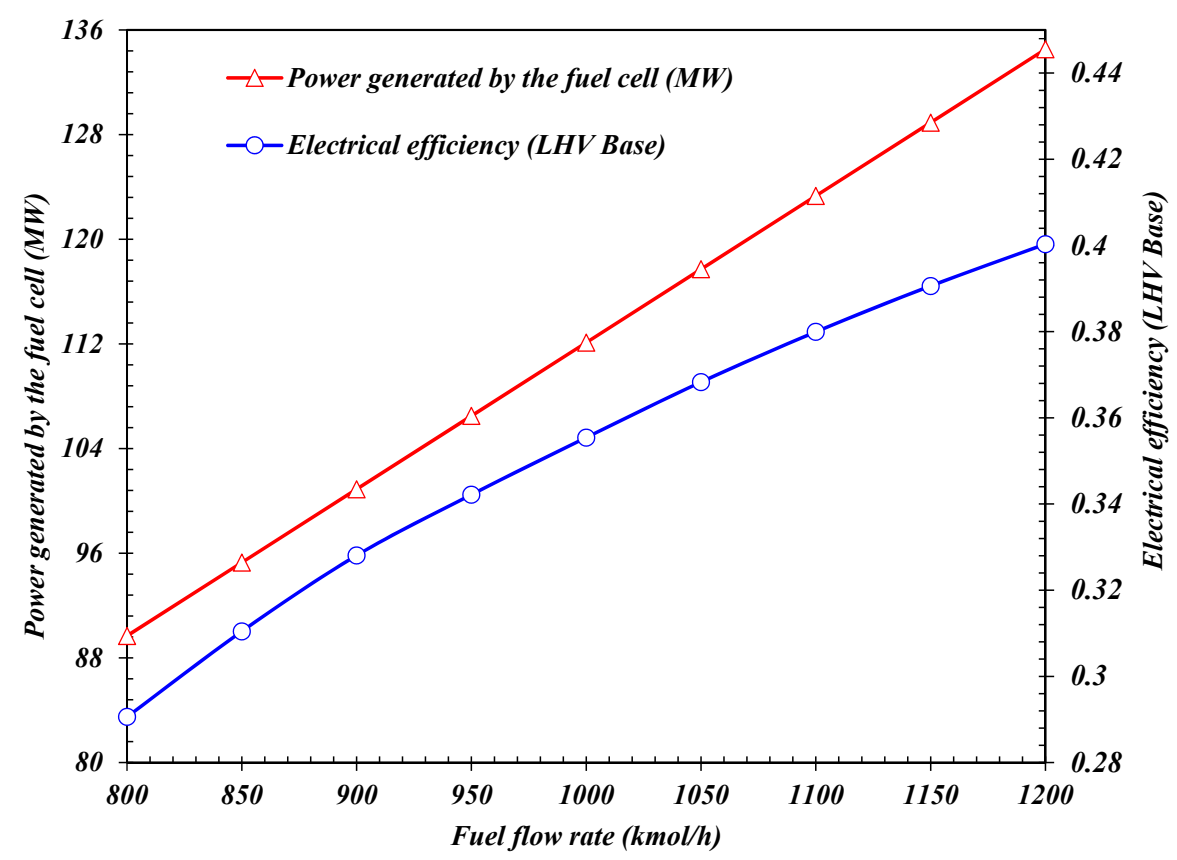

Figure 9. The changes in electricity generated by the fuel cell and electrical efficiency with the reduction in fuel input to the fuel cell.

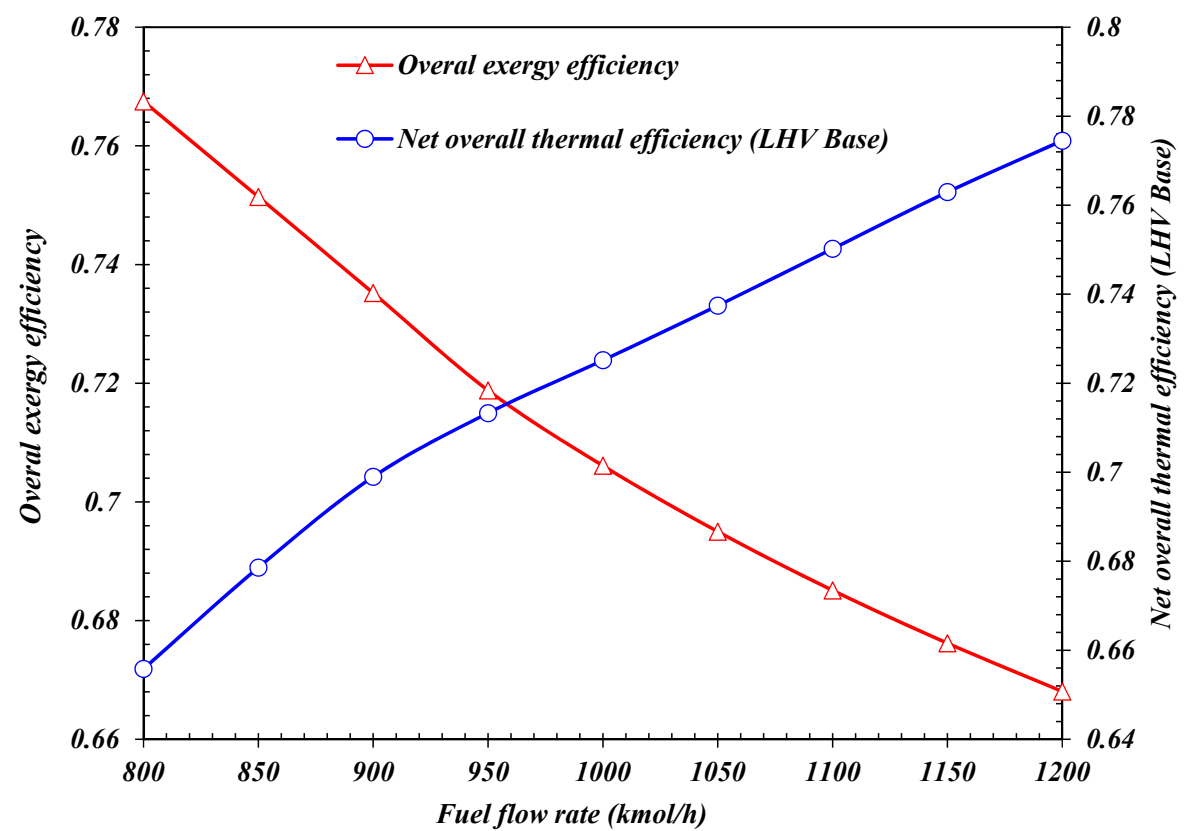

Figure 10. The variation of the net overall thermal efficiency and overall exergy efficiency with respect to the reduction in fuel input to the fuel cell. 


\section{Conclusions}

The storage of liquid carbon dioxide is a method of storing energy for long periods which is portable and can be used during peak hours. Providing the required electricity for the liquefaction cycle during off-peak hours is a concern of many researchers in this field. Using molten carbonate fuel cells as a source of high efficiency and low pollution power generation is one of the ways to provide electricity and heat to store energy during peak hours. In this research, a combined process for the production of electricity, medium pressure steam, and energy storage in the form of liquid carbon dioxide was developed. For co-production, a combination of a molten carbonate fuel cell, a dual pressure LindeHampson liquefaction plant and a heat recovery steam generator was used. The results of the energy and exergy analyses were as follows.

In this integrated structure, $4.202 \mathrm{~kg} / \mathrm{s}$ of natural gas and $144 \mathrm{~kg} / \mathrm{s}$ of carbon dioxide with impurities were the main input feed. The primary products of this integrated structure were $65.53 \mathrm{MW}$ of electricity, $27.80 \mathrm{~kg} / \mathrm{s}$ of medium pressure steam, and $142.9 \mathrm{~kg} / \mathrm{s}$ of liquid $\mathrm{CO}_{2}$. The thermal efficiency of the fuel cell, the total thermal efficiency of the entire integrated structure, and the performance coefficient of the liquefaction plant were $46.94 \%$, $82.21 \%$, and 1.866 , respectively. The results of the $\mathrm{CO}_{2}$ liquefaction plant validation showed that the performance coefficient of the developed refrigeration plant and the reference were 1.87 and 1.83, respectively. The low relative error of the compared parameters depends on the version of HYSYS software used for the simulation.

The output of the exergy investigation showed that fuel cells, heat exchangers, and compressors had the most exergy destruction with values of of $37.72 \%, 18.71 \%$, and 12.26 , respectively. Moreover, the heat exchangers had the highest exergy yield and the valves had the lowest exergy yield. The exergy efficiency and destruction of equipment results showed that the equipment with high exergy destruction shares, such as heat exchangers, also had high exergy efficiencies. Moreover, the equipment with low exergy efficiencies such as the expansion valves had a low exergy destruction share. Considering the above showed that the developed simulation had a high efficiency of $73.18 \%$.

The results obtained from the sensitivity analysis showed that a 50\% increase in fuel input to the fuel cell led to an increase in the electrical efficiency of the fuel cell and an increase in the thermal efficiency of the entire integrated structure by $37.75 \%$ and $18.09 \%$, respectively. Moreover, the exergy yield of the entire hybrid process was reduced by $12.95 \%$. Furthermore, by increasing the outlet pressure of the V1 expansion valve from 39 bar to 45 bar, the total cooling duty rate increased from 116.4 MW to $117 \mathrm{MW}$, and the refrigeration cycle performance coefficient decreased from 1.866 to 1.770.

As a suggestion for future works, the development of the power generation cycle in peak hours for network use could be mentioned. Advanced exergy and advanced exergoeconomic analyses could also be used to investigate the developed co-generation cycle.

Funding: This research received no external funding.

Institutional Review Board Statement: Not applicable.

Informed Consent Statement: Not applicable.

Data Availability Statement: Not applicable.

Conflicts of Interest: The author declares no conflict of interest. 


\section{Appendix A}

Table A1. Equations needed for the exergy analysis of the equipment employed in the developed integrated process [40-43].

\begin{tabular}{|c|c|c|}
\hline Equipment & Exergy Destruction & Exergy Efficiency \\
\hline Heat Exchangers & $\dot{\mathrm{X}}_{\text {des }}=\sum(\dot{\mathfrak{m}} x)_{\text {in }}-\sum(\dot{\mathfrak{m}} x)_{\text {out }}$ & $\eta_{e x}=1-\left(\frac{\sum \dot{\mathfrak{m}} \Delta x}{\sum \mathfrak{m} \Delta h}\right)_{h o t}+\left(\frac{\sum \dot{\mathfrak{m}} \Delta x}{\sum \mathfrak{m} \Delta h}\right)_{c o l d}$ \\
\hline Compressors and Pumps & $\dot{\mathrm{X}}_{\text {des }}=\dot{\mathcal{W}}+\sum(\dot{\mathfrak{m}} x)_{\text {in }}-\sum(\dot{\mathfrak{m}} x)_{\text {out }}$ & $\eta_{e x}=\frac{\sum(\dot{\mathfrak{m} x})_{\text {in }}-\sum(\dot{\mathfrak{m}} x)_{\text {out }}}{\dot{w}}$ \\
\hline Turbines & $\dot{\mathrm{X}}_{\text {des }}=-\dot{\mathcal{W}}+\sum(\dot{\mathfrak{m}} x)_{\text {in }}-\sum(\dot{\mathfrak{m}} x)_{\text {out }}$ & $\eta_{\text {ex }}=\frac{\dot{w}}{\sum(\mathfrak{m} x)_{\text {in }}-\sum(\mathfrak{m} x)_{\text {out }}}$ \\
\hline Expansion Valves & $\dot{\mathrm{X}}_{\text {des }}=\sum(\dot{\mathfrak{m}} x)_{\text {in }}-\sum(\dot{\mathfrak{m}} x)_{\text {out }}$ & $\eta_{e x}=\frac{x_{\text {out }}^{\Delta T}-x_{i n t}^{\Delta T}}{x_{\text {out }}^{\Delta P}-x_{i n}^{\Delta P}}$ \\
\hline Fuel Cell & $\dot{\mathrm{X}}_{\text {des }}=\sum(\dot{\mathfrak{m}} x)_{\text {in }}-\sum(\dot{\mathfrak{m}} x)_{\text {out }}$ & $\eta_{e x}=\frac{\sum(\dot{\mathfrak{m}} x)_{\text {out }}}{\sum(\dot{\mathfrak{m}} x)_{\text {in }}}$ \\
\hline Flash Drums & $\dot{\mathrm{X}}_{\text {des }}=\sum(\dot{\mathfrak{m}} x)_{\text {in }}-\sum(\dot{\mathfrak{m}} x)_{\text {out }}$ & $\eta_{\text {ex }}=\frac{\sum(\dot{\mathfrak{m}} x)_{\text {out }}}{\sum(\dot{\mathfrak{m}} x)_{\text {in }}}$ \\
\hline Cycle & $\dot{\mathrm{X}}_{\text {des }}=\sum(\dot{\mathfrak{m}} x)_{\text {in }}-\sum(\dot{\mathfrak{m}} x)_{\text {out }}$ & $\eta_{\text {ex }}=\frac{\sum(\mathfrak{m} x)_{\text {out }}}{\sum(\mathfrak{m} x)_{\text {in }}}$ \\
\hline
\end{tabular}

\section{Nomenclature}

\begin{tabular}{|c|c|}
\hline \multicolumn{2}{|c|}{ Abbreviations } \\
\hline $\mathrm{CCHP}$ & Combined cooling, heat and power \\
\hline MCFC & Molten carbonate fuel cells \\
\hline MFC & Mixed fluid cascade \\
\hline HRSG & Heat recovery steam generators \\
\hline $\mathrm{CO}_{2}$ & Carbon dioxide \\
\hline $\mathrm{CO}$ & Carbon monoxide \\
\hline $\mathrm{CH}_{4}$ & Methane \\
\hline $\mathrm{H}_{2} \mathrm{O}$ & Water \\
\hline $\mathrm{H}_{2}$ & Hydrogen \\
\hline$e^{2}$ & Exergy \\
\hline $\mathrm{Ph}$ & Physical \\
\hline $\mathrm{Ch}$ & Chemical \\
\hline$e^{p h}$ & Physical exergy \\
\hline $\mathrm{e}^{\mathrm{ch}}$ & Chemical exergy \\
\hline$e_{i}^{0}$ & Standard chemical exergy of any compound \\
\hline $\mathrm{T}$ & Temperature \\
\hline \multicolumn{2}{|c|}{ Greek Letters } \\
\hline$\Sigma$ & Sum \\
\hline$\gamma$ & Activity coefficient of component \\
\hline$\eta$ & Efficiency \\
\hline \multicolumn{2}{|c|}{ Components Name } \\
\hline HX & Heat exchanger \\
\hline $\mathrm{V}$ & Expansion valve \\
\hline $\mathrm{T}$ & Gas turbine \\
\hline C & Compressor \\
\hline $\mathrm{D}$ & Flash drum \\
\hline s & Entropy \\
\hline $\mathrm{h}$ & Enthalpy \\
\hline$\dot{W}$ & Work rate \\
\hline$\dot{I}$ & Lost exergy \\
\hline$Q$ & Heat \\
\hline $\mathrm{P}$ & Pressure \\
\hline
\end{tabular}




$\begin{array}{ll}\text { Superscripts and Subscripts } & \\ \text { Ex } & \text { exergy } \\ r e v & \text { reversible } \\ d & \text { dry } \\ \text { in } & \text { Inlet } \\ \text { irr } & \text { irreversible } \\ H X & \text { heat exchanger } \\ \text { out } & \text { outlet } \\ p & \text { pressure } \\ p h & \text { physical } \\ \text { s } & \text { isentropic } \\ \text { th } & \text { thermal } \\ \text { tot } & \text { total }\end{array}$

\section{References}

1. Açıkalp, E.; Chen, L.; Ahmadi, M.H. Comparative performance analyses of molten carbonate fuel cell-alkali metal thermal to electric converter and molten carbonate fuel cell-thermo-electric generator hybrid systems. Energy Rep. 2020, 6, 10-16. [CrossRef]

2. Campanari, S.; Manzolini, G.; Chiesa, P. Using MCFC for high efficiency $\mathrm{CO}_{2}$ capture from natural gas combined cycles: Comparison of internal and external reforming. Appl. Energy 2013, 112, 772-783. [CrossRef]

3. Pfafferodt, M.; Heidebrecht, P.; Sundmacher, K. Stack modelling of a molten carbonate fuel cell (MCFC). Fuel Cells 2010, 10, 619-635. [CrossRef]

4. Mamaghani, A.H.; Najafi, B.; Shirazi, A.; Rinaldi, F. Exergetic, economic, and environmental evaluations and multi-objective optimization of a combined molten carbonate fuel cell-gas turbine system. Appl. Therm. Eng. 2015, 77, 1-11. [CrossRef]

5. Mamaghani, A.H.; Najafi, B.; Shirazi, A.; Rinaldi, F. 4E analysis and multi-objective optimization of an integrated MCFC (molten carbonate fuel cell) and ORC (organic Rankine cycle) system. Energy 2015, 82, 650-663. [CrossRef]

6. Marefati, M.; Mehrpooya, M. Introducing and investigation of a combined molten carbonate fuel cell, thermoelectric generator, linear fresnel solar reflector and power turbine combined heating and power process. J. Clean. Prod. 2019, 240, 118247. [CrossRef]

7. Ahmadi, M.H.; Jokar, M.A.; Ming, T.; Feidt, M.; Pourfayaz, F.; Astaraei, F.R. Multi-objective performance optimization of irreversible molten carbonate fuel cell-Braysson heat engine and thermodynamic analysis with ecological objective approach. Energy 2018, 144, 707-722. [CrossRef]

8. Ahmadi, M.H.; Sameti, M.; Pourkiaei, S.M.; Ming, T.; Pourfayaz, F.; Chamkha, A.J.; Oztop, H.F.; Jokar, M.A. Multi-objective performance optimization of irreversible molten carbonate fuel cell-Stirling heat engine-reverse osmosis and thermodynamic assessment with ecological objective approach. Energy Sci. Eng. 2018, 6, 783-796. [CrossRef]

9. Jokar, M.A.; Ahmadi, M.H.; Sharifpur, M.; Meyer, J.P.; Pourfayaz, F.; Ming, T. Thermodynamic evaluation and multi-objective optimization of molten carbonate fuel cell-supercritical $\mathrm{CO}_{2}$ Brayton cycle hybrid system. Energy Convers. Manag. 2017, 153, 538-556. [CrossRef]

10. Ryu, J.-Y.; Ko, A.; Park, S.-H.; Park, J.-P. Thermo-economic assessment of molten carbonate fuel cell hybrid system combined between individual $\mathrm{sCO}_{2}$ power cycle and district heating. Appl. Therm. Eng. 2020, 169, 114911. [CrossRef]

11. Haghghi, M.A.; Shamsaiee, M.; Holagh, S.G.; Chitsaz, A.; Rosen, M.A. Thermodynamic, exergoeconomic, and environmental evaluation of a new multi-generation system driven by a molten carbonate fuel cell for production of cooling, heating, electricity, and freshwater. Energy Convers. Manag. 2019, 199, 112040. [CrossRef]

12. Liu, A.; Weng, Y. Modeling of molten carbonate fuel cell based on the volume-resistance characteristics and experimental analysis. J. Power Sources 2010, 195, 1872-1879. [CrossRef]

13. Carrette, L.; Friedrich, K.A.; Stimming, U. Fuel cells: Principles, types, fuels, and applications. ChemPhysChem 2000, 1, 162-193. [CrossRef]

14. Rashidi, R.; Berg, P.; Dincer, I. Performance investigation of a combined MCFC system. Int. J. Hydrogen Energy. 2009, 34, 4395-4405. [CrossRef]

15. Kang, B.S.; Koh, J.-H.; Lim, H.C. Effects of system configuration and operating condition on MCFC system efficiency. J. Power Sources 2002, 108, 232-238. [CrossRef]

16. Xu, M.; Zhao, P.; Huo, Y.; Han, J.; Wang, J.; Dai, Y. Thermodynamic analysis of a novel liquid carbon dioxide energy storage system and comparison to a liquid air energy storage system. J. Clean. Prod. 2020, 242, 118437. [CrossRef]

17. Liu, J.; Chen, H.; Xu, Y.; Wang, L.; Tan, C. A solar energy storage and power generation system based on supercritical carbon dioxide. Renew. Energy 2014, 64, 43-51. [CrossRef]

18. Aliyon, K.; Mehrpooya, M.; Hajinezhad, A. Comparison of different $\mathrm{CO}_{2}$ liquefaction processes and exergoeconomic evaluation of integrated $\mathrm{CO}_{2}$ liquefaction and absorption refrigeration system. Energy Convers. Manag. 2020, 211, 112752. [CrossRef]

19. Shakib, S.E.; Amidpour, M.; Aghanajafi, C. Simulation and optimization of multi effect desalination coupled to a gas turbine plant with HRSG consideration. Desalination 2012, 285, 366-376. [CrossRef]

20. Hosseini, S.R.; Amidpour, M.; Shakib, S.E. Cost optimization of a combined power and water desalination plant with exergetic, environment and reliability consideration. Desalination 2012, 285, 123-130. [CrossRef] 
21. Akrami, E.; Ameri, M.; Rocco, M.V. Integration of biomass-fueled power plant and $\mathrm{MCFC}$-cryogenic $\mathrm{CO}_{2}$ separation unit for low-carbon power production: Thermodynamic and exergoeconomic comparative analysis. Energy Convers. Manag. 2020, 223, 113304. [CrossRef]

22. Ebrahimi-Moghadam, A.; Moghadam, A.J.; Farzaneh-Gord, M.; Aliakbari, K. Proposal and assessment of a novel combined heat and power system: Energy, exergy, environmental and economic analysis. Energy Convers. Manag. 2020, 204, 112307. [CrossRef]

23. Tabrizi, A.H.; Niazmand, H.; Farzaneh-Gord, M.; Ebrahimi-Moghadam, A. Energy, exergy and economic analysis of utilizing the supercritical $\mathrm{CO}_{2}$ recompression Brayton cycle integrated with solar energy in natural gas city gate station. J. Therm. Anal. Calorim. 2020, 9, 1-9.

24. Ebrahimi-Moghadam, A.; Moghadam, A.J.; Farzaneh-Gord, M.; Arabkoohsar, A. Performance investigation of a novel hybrid system for simultaneous production of cooling, heating, and electricity. Sustain. Energy Technol. Assess. 2021, 12, 43.

25. Ghorbani, B.; Salehi, G.; Ebrahimi, A.; Taghavi, M. Energy, exergy and pinch analyses of a novel energy storage structure using post-combustion $\mathrm{CO}_{2}$ separation unit, dual pressure Linde-Hampson liquefaction system, two-stage organic Rankine cycle and geothermal energy. Energy 2021, 1, 121051. [CrossRef]

26. Ebrahimi-Moghadam, A.; Moghadam, A.J.; Farzaneh-Gord, M. Comprehensive techno-economic and environmental sensitivity analysis and multi-objective optimization of a novel heat and power system for natural gas city gate stations. J. Clean. Prod. 2020, 262, 121261. [CrossRef]

27. Ebrahimi-Moghadam, A.; Farzaneh-Gord, M.; Moghadam, A.J.; Abu-Hamdeh, N.H.; Lasemi, M.A.; Arabkoohsar, A.; Alimoradi, A. Design and multi-criteria optimisation of a trigeneration district energy system based on gas turbine, Kalina, and ejector cycles: Exergoeconomic and exergoenvironmental evaluation. Energy Convers. Manag. 2021, 227, 113581. [CrossRef]

28. Spiegel, C. PEM Fuel Cell Modeling and Simulation Using Matlab; Elsevier Science: Burlington, UK, 2011.

29. Ebrahimi, A.; Ghorbani, B.; Ziabasharhagh, M. Introducing a novel integrated cogeneration system of power and cooling using stored liquefied natural gas as a cryogenic energy storage system. Energy 2020, 206, 117982. [CrossRef]

30. Larminie, J.; Dicks, A.; McDonald, M.S. Fuel Cell Systems Explained; J. Wiley: Chichester, UK, 2003.

31. Duan, L.; Lu, H.; Yuan, M.; Lv, Z. Optimization and part-load performance analysis of MCFC/ST hybrid power system. Energy 2018, 152, 682-693. [CrossRef]

32. Duan, L.; Yue, L.; Qu, W.; Yang, Y. Study on $\mathrm{CO}_{2}$ capture from molten carbonate fuel cell hybrid system integrated with oxygen ion transfer membrane. Energy 2015, 93, 20-30. [CrossRef]

33. Hongliang, H.; Zhang, H.; Weng, S.; Su, M. Dynamic numerical simulation of a molten carbonate fuel cell. J. Power Sources 2006, 161, 849-855. [CrossRef]

34. Kotas, T.J. The Exergy Method of Thermal Plant Analysis; Elsevier: London, UK, 2013.

35. Mohammadi, A.; Ahmadi, M.H.; Bidi, M.; Ghazvini, M.; Ming, T. Exergy and economic analyses of replacing feedwater heaters in a Rankine cycle with parabolic trough collectors. Energy Rep. 2018, 4, 243-251. [CrossRef]

36. Parikhani, T.; Ghaebi, H.; Rostamzadeh, H. A novel geothermal combined cooling and power cycle based on the absorption power cycle: Energy, exergy and exergoeconomic analysis. Energy 2018, 153, 265-277. [CrossRef]

37. Ghaebi, H.; Parikhani, T.; Rostamzadeh, H. A novel trigeneration system using geothermal heat source and liquefied natural gas cold energy recovery: Energy, exergy and exergoeconomic analysis. Renew. Energy 2018, 119, 513-527. [CrossRef]

38. Ghaebi, H.; Parikhani, T.; Rostamzadeh, H. Energy, exergy and thermoeconomic analysis of a novel combined cooling and power system using low-temperature heat source and LNG cold energy recovery. Energy Convers. Manag. 2017, 150, 678-692. [CrossRef]

39. Mohammed, H.; Al-Othman, A.; Nancarrow, P.; Tawalbeh, M.; Assad, M.E.H. Direct hydrocarbon fuel cells: A promising technology for improving energy efficiency. Energy 2019, 172, 207-219. [CrossRef]

40. Sadaghiani, M.S.; Mehrpooya, M.; Ansarinasab, H. Process development and exergy cost sensitivity analysis of a novel hydrogen liquefaction process. Int. J. Hydrogen Energy 2017, 42, 29797-29819. [CrossRef]

41. Hosseinpour, S.; Aghbashlo, M.; Tabatabaei, M.; Younesi, H.; Mehrpooya, M.; Ramakrishna, S. Multi-objective exergy-based optimization of a continuous photobioreactor applied to produce hydrogen using a novel combination of soft computing techniques. Int. J. Hydrogen Energy 2017, 42, 8518-8529. [CrossRef]

42. Marefati, M.; Mehrpooya, M.; Mousavi, S.A. Introducing an integrated SOFC, linear Fresnel solar field, Stirling engine and steam turbine combined cooling, heating and power process. Int. J. Hydrogen Energy 2019, 44, 30256-30279. [CrossRef]

43. Pourfayaz, F.; Imani, M.; Mehrpooya, M.; Shirmohammadi, R. Process development and exergy analysis of a novel hybrid fuel cell-absorption refrigeration system utilizing nanofluid as the absorbent liquid. Int. J. Refrig. 2019, 97, 31-41. [CrossRef] 